\title{
PHYSICAL PROPERTIES OF KAOLIN/SAND SLURRY USED DURING SUBMERSIBLE MIXER PUMP TESTS AT TNX
}

\author{
Author: $\quad$ Erich Hansen \\ Vickie Williams
}

August 2004 
This document was prepared in conjunction with work accomplished under Contract No. DE-AC09-96SR18500 with the U. S. Department of Energy.

\section{DISCLAIMER}

This report was prepared as an account of work sponsored by an agency of the United States Government. Neither the United States Government nor any agency thereof, nor any of their employees, makes any warranty, express or implied, or assumes any legal liability or responsibility for the accuracy, completeness, or usefulness of any information, apparatus, product or process disclosed, or represents that its use would not infringe privately owned rights. Reference herein to any specific commercial product, process or service by trade name, trademark, manufacturer, or otherwise does not necessarily constitute or imply its endorsement, recommendation, or favoring by the United States Government or any agency thereof. The views and opinions of authors expressed herein do not necessarily state or reflect those of the United States Government or any agency thereof.

This report has been reproduced directly from the best available copy.

Available for sale to the public, in paper, from: U.S. Department of Commerce, National Technical Information Service, 5285 Port Royal Road, Springfield, VA 22161, phone: (800) 553-6847, fax: (703) 605-6900

email: orders@ntis.fedworld.gov

online ordering: http://www.ntis.gov/help/index.asp

Available electronically at http://www.osti.gov/bridge

Available for a processing fee to U.S. Department of Energy and its contractors, in paper, from: U.S. Department of Energy, Office of Scientific and Technical Information, P.O. Box 62, Oak Ridge, TN 37831-0062,

phone: (865)576-8401,

fax: (865)576-5728

email: $\underline{\text { reports@ adonis.osti.gov }}$ 
WSRC-TR-2004-00401

Revision 0

Key Words: Kaolin, physical properties

Retention: Permanent

\section{PHYSICAL PROPERTIES OF KAOLIN/SAND SLURRY USED DURING SUBMERSIBLE MIXER PUMP TESTS AT TNX}

Author: Erich Hansen

Vickie Williams

August 2004 
This page was intentionally left blank 


\section{EXECUTIVE SUMMARY}

The purpose of this task is to characterize the physical properties of kaolin/sand slurry used to test the performance of a new submersible mixer pump (SMP) which is undergoing performance testing at the TNT Waste Tank mockup facility. Three different sample locations, the SMP cooling water exit (CWE), the SMP fluid flow field (FFF), and SMP effective cleaning radius (ECR) were used for sampling over the seven day test. The physical properties determinations for the kaolin/sand slurry samples include rheology, weight percent total solids (wt $\%$ TS), density, and particle size distribution (PSD) were requested, though not all these determinations were performed on all the samples.

The physical properties determinations are described in more detail in section 1.0. Measurements were performed at Savannah River National Laboratory (SRNL) in accordance with the Technical Assistance Request (TAR) ${ }^{1}$.

The data, average of two measurements, is shown in the table below. This data clearly shows that the SMP-CWE samples contained more solids than those at other sample locations for a given sample day. The SMP-FFF and SMP-ECR were similar in solids content. The rheology of the samples is dependent on the $\mathrm{wt} \%$ solids concentration and are all within the bounds stated in the TAR. The particle size distribution is discussed in section 1.4.

\begin{tabular}{|c|c|c|c|c|c|}
\hline \multirow{2}{*}{$\begin{array}{l}\text { Sample } \\
\text { location }\end{array}$} & \multirow{2}{*}{$\begin{array}{l}\text { Day } \\
\text { Pulled }\end{array}$} & \multicolumn{4}{|c|}{ Average of Two Measurements } \\
\hline & & wt $\%$ T.S. & Density $(\mathrm{g} / \mathrm{mL})$ & $\begin{array}{l}\text { Yield stress } \\
\left(\text { dynes } / \mathrm{cm}^{2}\right)\end{array}$ & $\begin{array}{c}\text { Consistency } \\
\text { (cP) }\end{array}$ \\
\hline \multirow{7}{*}{ SMP-CWE } & 1 & 25.17 & 1.180 & 122.0 & 8.04 \\
\hline & 2 & 24.04 & 1.171 & 107.9 & 7.52 \\
\hline & 3 & 23.86 & 1.171 & 107.6 & 7.43 \\
\hline & 4 & 23.89 & 1.173 & 109.2 & 7.42 \\
\hline & 5 & 23.01 & 1.165 & 95.6 & 6.86 \\
\hline & 6 & 23.02 & 1.164 & 99.0 & 7.03 \\
\hline & 7 & 23.23 & 1.167 & 97.9 & 7.03 \\
\hline \multirow{7}{*}{ SMP-FFF } & 1 & 24.32 & 1.177 & $\mathrm{~N} / \mathrm{M}$ & $\mathrm{N} / \mathrm{M}$ \\
\hline & 2 & 23.72 & 1.167 & $\mathrm{~N} / \mathrm{M}$ & $\mathrm{N} / \mathrm{M}$ \\
\hline & 3 & 23.49 & 1.165 & $\mathrm{~N} / \mathrm{M}$ & $\mathrm{N} / \mathrm{M}$ \\
\hline & 4 & 23.41 & 1.169 & $\mathrm{~N} / \mathrm{M}$ & $\mathrm{N} / \mathrm{M}$ \\
\hline & 5 & 22.77 & 1.162 & $\mathrm{~N} / \mathrm{M}$ & $\mathrm{N} / \mathrm{M}$ \\
\hline & 6 & 22.69 & 1.161 & $\mathrm{~N} / \mathrm{M}$ & $\mathrm{N} / \mathrm{M}$ \\
\hline & 7 & 22.92 & 1.164 & $\mathrm{~N} / \mathrm{M}$ & $\mathrm{N} / \mathrm{M}$ \\
\hline \multirow{3}{*}{ SMP-ECR } & 3 & 23.51 & 1.168 & 104.3 & 7.21 \\
\hline & 6 & 22.06 & 1.157 & 83.3 & 6.39 \\
\hline & 7 & 22.97 & 1.165 & 96.7 & 6.98 \\
\hline
\end{tabular}

\footnotetext{
${ }^{1}$ Altman, D., "Testing and Sampling support at TNX for Submersible Mixer Pump (SPM) Test", HAL-TAR2004-077, Rev. 1, July 21, 2004
} 


\section{TABLE OF CONTENTS}

EXECUTIVE SUMMARY iii

LIST OF FIGURES $\quad$ V

LIST OF TABLES vi

LIST OF ACRONYMS vii

1.0 INTRODUCTION AND BACKGROUND 1

1.1 Weight Percent Total Solids 2

1.2 Density

1.3 Rheology

1.4 Particle Size Distribution

2.0 Reference 11

APPENDIX A. $1^{\text {st }}$ Sample down flow curves fitted to bingham plastic model 12

APPENDIX B. Particle size distributuion $\quad 18$

APPENDIX C: Kaolin Vendor B-100 Specifications 33 


\section{LIST OF FIGURES}

Figure 1-1: Typical Kaolin/Sand Flow Curve of an SMP Sample .................................... 6

Figure 1-2: Density Versus Wt\% TS For SMP................................................................ 7

Figure 1-3: Bingham Plastic Yield Stress Versus Wt\% TS For SMP .............................. 8

Figure 1-4: Bingham Plastic Consistency Versus Wt\% TS For SMP ................................ 8

Figure A - 1: Down Flow Curve Sample SMP-CWE-1, Run 1 ......................................... 13

Figure A - 2: Down Flow Curve Sample SMP-CWE-2, Run 1 ......................................... 13

Figure A - 3: Down Flow Curve Sample SMP-CWE-3, Run 1 ........................................... 14

Figure A - 4: Down Flow Curve Sample SMP-CWE-4, Run 1 .......................................... 14

Figure A - 5: Down Flow Curve Sample SMP-CWE-5, Run 1 ........................................... 15

Figure A - 6: Down Flow Curve Sample SMP-CWE-6, Run 1 .......................................... 15

Figure A - 7: Down Flow Curve Sample SMP-CWE-7, Run 1 ......................................... 16

Figure A - 8: Down Flow Curve Sample SMP-ECR-3, Run 1 .......................................... 16

Figure A - 9: Down Flow Curve Sample SMP-CWE-6, Run 1 ......................................... 17

Figure A - 10: Down Flow Curve Sample SMP-CWE-3, Run 1 ....................................... 17

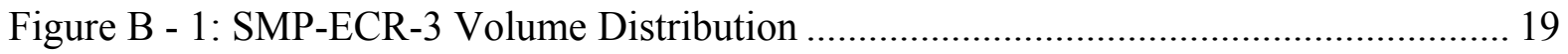

Figure B - 2: SMP-ECR-3 Number Distribution ............................................................. 20

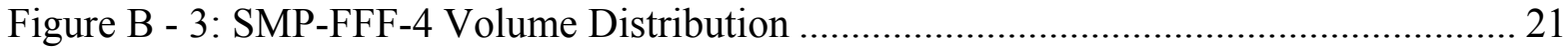

Figure B - 4: SMP-FFF-4 Number Distribution ....................................................... 22

Figure B - 5: SMP-CWE-4 Volume Distribution ...................................................... 23

Figure B - 6: SMP-CWE-4 Number Distribution ........................................................ 24

Figure B - 7: SMP-ECR-6 Volume Distribution .............................................................. 25

Figure B - 8: SMP-ECR-6 Number Distribution ................................................................ 26

Figure B - 9: SMP-ECR-7 Volume Distribution ............................................................ 27

Figure B - 10: SMP-ECR-7 Number Distribution ....................................................... 28

Figure B - 11: SMP-FFF-7 Volume Distribution ............................................................. 29

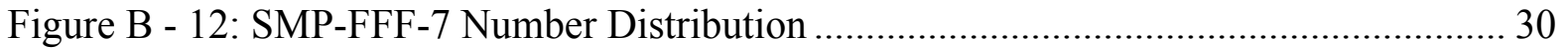

Figure B - 13: SMP-CWE-7 Volume Distribution ................................................... 31

Figure B - 14: SMP-CWE-7 Number Distribution ........................................................ 32 


\section{LIST OF TABLES}

Table 1-1: Analysis Requested of Provided Samples ............................................................ 1

Table 1-2: Sample Location and Method of Sampling for the SMP Test ................................ 1

Table 1-3: Kaolin/Sand Weight Percent Total Solids Data for the SMP.................................. 3

Table 1-4: Kaolin/Sand Density Data for the SMP ............................................................... 4

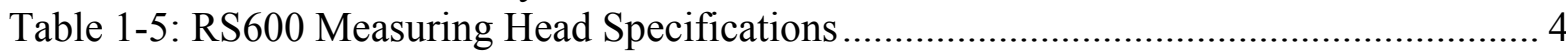

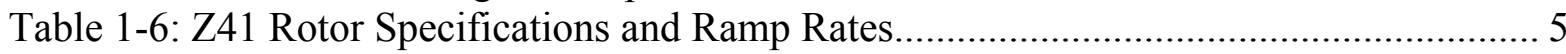

Table 1-7: Cole-Parmer NIST Traceable Newtonian Oil Standard ......................................... 5

Table 1-8: Kaolin/Sand Bingham Plastic Rheological Data for the SMP ……………........... 7

Table 1-9: Unimin B-100 Kaolin PSD - Percent Weight on Oxide Basis ................................ 9

Table 1-10: ASTM Specification for Aggregate (Sand) Used in SMP Test.............................. 9

Table 1-11: PSD of Aggregate (Sand) Provided to SRNL .................................................. 10

Table 1-12: Mean Volume and Number Particle Size Diameters for SMP Samples ............. 11 


\section{LIST OF ACRONYMS}

ACTL Aiken County Technology Laboratories

ADS Analytical Developmental Section

CWE Cooling Water Exit

DI De-ionized

ECR Effective Cleaning Radius

FFF Fluid Flow Field

ITS Immobilization Technology Section

NIST National Institute of Standards and Technology

N/M Not Measured

PSD Particle Size Distribution

SMP Submersible Mixer Pump

SRNL Savannah River National Laboratory

TAR Technical Assistance Request

WOW Waste on Wheels

wt $\%$ TS Weight Percent Total Solids 


\subsection{INTRODUCTION AND BACKGROUND}

Waste on Wheels (WOW) engineering requested ${ }^{\mathbf{1}}$ SRNL Immobilization Technology Section (ITS) to perform physical characterization of the kaolin/sand slurry used to characterize the performance of a new SMP. The testing of the new SMP was performed at the TNX Waste Tank mockup facility. During the $7^{2}$ day SMP test using the kaolin/sand slurry, samples were pulled from three different locations. The sampling day, sample location, and requested physical property analyses are shown in Table 1-1.

Table 1-1: Analysis Requested of Provided Samples

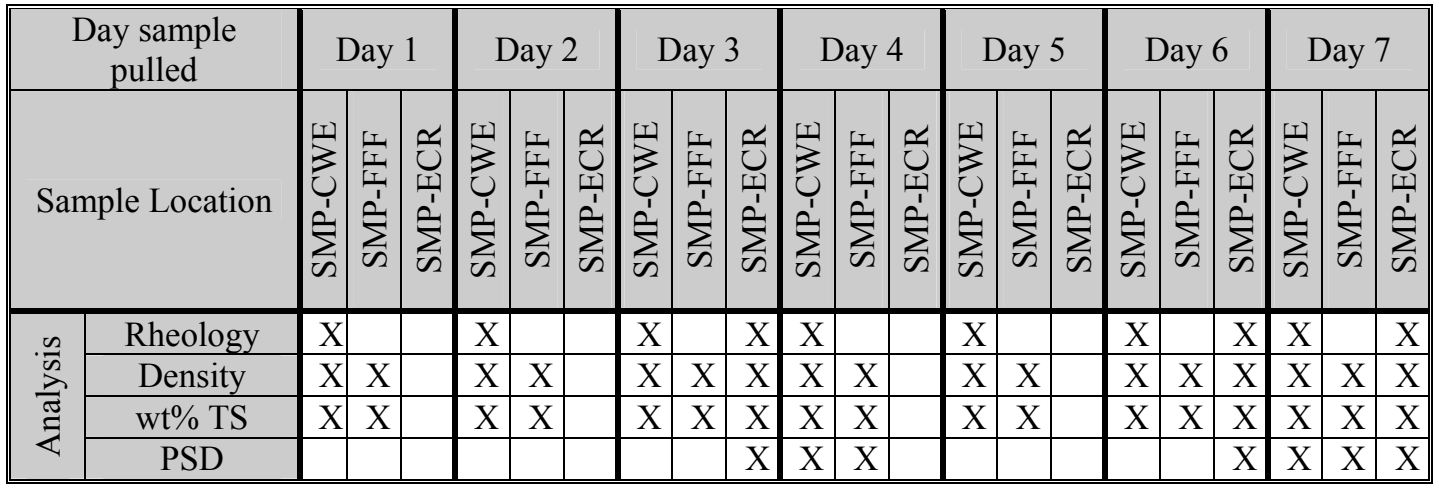

Blanks mean specified analysis was not requested for this sample.

The location and method of sampling is provided in Table 1-2. A $400 \mathrm{~mL}$ sample at each sample location per day was required to complete the necessary physical characterization.

Table 1-2: Sample Location and Method of Sampling for the SMP Test

\begin{tabular}{|c|c|}
\hline Location & Sampling Method \\
\hline $\begin{array}{l}\text { SMP - Cooling Water } \\
\text { Exit }(\mathrm{CWE})\end{array}$ & $\begin{array}{l}\text { There are four discharge motor cooling streams leaving the motor housing. A clean } \\
\text { stainless steel beaker will be used to gather a sample from the discharge and sample(s) } \\
\text { poured into a sample bottle. The sample cup was wetted with the CWE prior to } \\
\text { sampling. }\end{array}$ \\
\hline $\begin{array}{l}\text { SMP - Fluid Flow Field } \\
\text { (FFF) }\end{array}$ & $\begin{array}{l}\text { A pump was used to pull a sample from the discharge of the rotating SMP. The sample } \\
\text { was pulled two feet from the bottom of the tank when the jet rotated into the sampling } \\
\text { location. }\end{array}$ \\
\hline $\begin{array}{c}\text { SMP - Effective } \\
\text { Cleaning Radius (ECR) }\end{array}$ & $\begin{array}{l}\text { A dip sample ( } 1 \text { to } 3 \text { feet deep) was collected from a stagnant zone near the edge of the } \\
\text { tank opposite of the SMP. }\end{array}$ \\
\hline
\end{tabular}

Once the samples were received at SRNL, samples that required PSD analysis were pulled and delivered to the Analytical Development Section (ADS) for analysis. Prior to pulling the sample, the sample bottles were homogenized. The remaining analyses occurred at Aiken County

\footnotetext{
${ }^{2}$ Kaolin/Sand slurry samples from the SMP testing were sampled from July $15^{\text {th }}$ through July $21^{\text {st }}, 2004$.
} 
Technology Laboratories (ACTL). The following sections describe the method used to perform the various analyses, the results, and any conclusions.

Prior to any measurement at ACTL, the samples were homogenized. Additional handling of the sample was performed prior to rheological measurements and is described in more detail in the rheology section.

\subsection{Weight Percent Total Solids}

Weight percent total solids were performed using a Mettler Toledo HR83 Halogen Moisture analyzer. This moisture analyzer uses a load cell that continuously measures the mass of the sample during the measurement and a halogen heat lamp that is controlled by an infrared thermometer. The mass of a sample pan is first measured and the weight tared. Approximately a 1.5 to 3 gram sub-sample of the kaolin/sand sample is placed onto the sample pan and this mass is recorded by the analyzer. The temperature of the sample is then ramped to $105^{\circ} \mathrm{C}$ and maintained at $105^{\circ} \mathrm{C}$ throughout the measurement. The temperature is maintained until the weight of the sample does not change more than 1 milligram over a 20 second period and this final mass is recorded by the analyzer. The $\mathrm{wt} \% \mathrm{TS}$ is then determined by taking the ratio of the final mass to initial mass and multiplying this value by $100 \%$. The analyzer load cell is checked on a daily basis (when used) using a 2.0 gram weight and functionally checked using a $7.0 \mathrm{wt} \%$ salt solution.

For each sample that required $\mathrm{wt} \% \mathrm{TS}$, two replicates were analyzed. The individual results, average and percent standard deviation are shown in Table 1-3. There were no limits provided in the TAR stating the range in which the wt $\%$ TS must be within. The SMP procurement specification $^{3}$ states $\mathrm{wt} \%$ solids range of 0 to $17 \%$ (section 3.3.1.1) for tank environmental conditions and a $20 \mathrm{wt} \%$ TS (section 4.1.3) for SMP acceptance testing. In both case, the wt $\%$ TS of the kaolin/sand slurries exceeded these limits. The data does reveal that samples pulled on the same day, the CWE samples are slightly higher in wt $\%$ TS as compared to the FFF and ECR samples. The FFF and ECR samples pulled on the same days have similar wt\% TS results.

\footnotetext{
${ }^{3}$ M-SPP-G-00302, "Procurement Specification - Submersible Mixer Pump”, Rev. 1, May 23, 2003
} 
Table 1-3: Kaolin/Sand Weight Percent Total Solids Data for the SMP

\begin{tabular}{||c|c|c|c|c|c||}
\hline \multirow{3}{*}{ Sample location } & \multirow{2}{*}{$\begin{array}{c}\text { Day } \\
\end{array}$} & \multicolumn{4}{|c|}{ Weight Percent Total Solids } \\
\cline { 2 - 6 } & Sample 1 & Sample 2 & Average & $\begin{array}{c}\text { \% standard } \\
\text { deviation }\end{array}$ \\
\hline \multirow{5}{*}{ SMP-CWE } & 1 & 25.25 & 25.08 & 25.17 & $0.48 \%$ \\
\cline { 2 - 6 } & 2 & 24.03 & 24.04 & 24.04 & $0.03 \%$ \\
\cline { 2 - 6 } & 3 & 23.80 & 23.91 & 23.86 & $0.33 \%$ \\
\cline { 2 - 6 } & 4 & 23.84 & 23.94 & 23.89 & $0.30 \%$ \\
\cline { 2 - 6 } & 5 & 22.93 & 23.08 & 23.01 & $0.46 \%$ \\
\cline { 2 - 6 } & 6 & 22.90 & 23.13 & 23.02 & $0.71 \%$ \\
\cline { 2 - 6 } & 7 & 23.29 & 23.17 & 23.23 & $0.37 \%$ \\
\hline \multirow{5}{*}{ SMP-FFF } & 1 & 24.22 & 24.42 & 24.32 & $0.58 \%$ \\
\cline { 2 - 6 } & 2 & 23.84 & 23.60 & 23.72 & $0.72 \%$ \\
\cline { 2 - 6 } & 3 & 23.48 & 23.49 & 23.49 & $0.03 \%$ \\
\cline { 2 - 6 } & 4 & 23.44 & 23.38 & 23.41 & $0.18 \%$ \\
\cline { 2 - 6 } & 5 & 22.71 & 22.82 & 22.77 & $0.34 \%$ \\
\cline { 2 - 6 } & 6 & 22.81 & 22.56 & 22.69 & $0.78 \%$ \\
\cline { 2 - 6 } & 7 & 22.90 & 22.94 & 22.92 & $0.12 \%$ \\
\hline \multirow{5}{*}{ SMP-ECR } & 3 & 23.58 & 23.44 & 23.51 & $0.42 \%$ \\
\cline { 2 - 6 } & 6 & 22.13 & 21.99 & 22.06 & $0.45 \%$ \\
\cline { 2 - 6 } & 7 & 22.93 & 23.01 & 22.97 & $0.25 \%$ \\
\hline
\end{tabular}

\subsection{Density}

Densities were performed using an Anton Paar DMA 4500 Density analyzer. A sample is pushed in to the density analyzer u-tube, the sample temperature corrected to $25^{\circ} \mathrm{C}$, a vibration is induced on one end of the u-tube and the frequency is measured at the other end. The density of the sample is determined on the measured frequency. The density analyzer is functionally checked on a daily basis (when used) with DI water.

For each sample that required density, two replicates were analyzed. The individual results, average and percent standard deviation are shown in Table 1-4. Specific gravity testing limits provided in the SMP procurement specification ranged from 1.0 to 1.5 (section 3.3.1.1) for the $^{3}$ supernatant but also specified testing the SMP using a kaolin slurry with a specific gravity of 1.14 (page 14$)^{4}$ for acceptance testing. The density of the kaolin/sand slurry samples were above the specific gravity for acceptance testing. The data reveals that samples pulled on the same day the CWE samples have a higher density as compared to the FFF and ECR samples and this is supported by the $\mathrm{wt} \% \mathrm{TS}$ data. The FFF and ECR samples pulled on the same day have similar density results.

\footnotetext{
${ }^{4}$ M-DCF-F-03629
} 
Table 1-4: Kaolin/Sand Density Data for the SMP

\begin{tabular}{|c|c|c|c|c|c|}
\hline \multirow[b]{2}{*}{ Sample location } & \multirow{2}{*}{$\begin{array}{l}\text { Day } \\
\text { Pulled }\end{array}$} & \multicolumn{4}{|c|}{ Density $(\mathrm{g} / \mathrm{mL})$} \\
\hline & & Sample 1 & Sample 2 & Average & $\begin{array}{c}\text { \% standard } \\
\text { deviation }\end{array}$ \\
\hline \multirow{7}{*}{ SMP-CWE } & 1 & 1.180 & 1.180 & 1.180 & $0.02 \%$ \\
\hline & 2 & 1.171 & 1.171 & 1.171 & $0.01 \%$ \\
\hline & 3 & 1.171 & 1.171 & 1.171 & $0.00 \%$ \\
\hline & 4 & 1.173 & 1.173 & 1.173 & $0.00 \%$ \\
\hline & 5 & 1.165 & 1.165 & 1.165 & $0.00 \%$ \\
\hline & 6 & 1.164 & 1.164 & 1.164 & $0.00 \%$ \\
\hline & 7 & 1.167 & 1.167 & 1.167 & $0.01 \%$ \\
\hline \multirow{7}{*}{ SMP-FFF } & 1 & 1.177 & 1.177 & 1.177 & $0.00 \%$ \\
\hline & 2 & 1.167 & 1.167 & 1.167 & $0.00 \%$ \\
\hline & 3 & 1.165 & 1.165 & 1.165 & $0.00 \%$ \\
\hline & 4 & 1.169 & 1.169 & 1.169 & $0.00 \%$ \\
\hline & 5 & 1.162 & 1.162 & 1.162 & $0.01 \%$ \\
\hline & 6 & 1.161 & 1.161 & 1.161 & $0.01 \%$ \\
\hline & 7 & 1.164 & 1.164 & 1.164 & $0.00 \%$ \\
\hline \multirow{3}{*}{ SMP-ECR } & 3 & 1.168 & 1.168 & 1.168 & $0.01 \%$ \\
\hline & 6 & 1.157 & 1.157 & 1.157 & $0.01 \%$ \\
\hline & 7 & 1.165 & 1.165 & 1.165 & $0.00 \%$ \\
\hline
\end{tabular}

\subsection{Rheology}

The Haake RS 600 rheometer was used for all rheological measurements performed in this task. Published RS600 specifications are shown in Table 1-5. The samples for rheological measurements were shaken for at least 1 minute prior to the initial measurement and the sample was shaken for at least 30 seconds prior to the second measurement.

Table 1-5: RS600 Measuring Head Specifications

\begin{tabular}{|c|c|c|}
\hline Specification & Units & Value \\
\hline Maximum Torque & $\mathrm{N}-\mathrm{m}$ & $0.5 \times 10^{-7}$ \\
\hline Minimum Torque (recommended) & $\mathrm{N}-\mathrm{m}$ & 0.2 \\
\hline Maximum Speed & $\mathrm{RPM}$ & 1500 \\
\hline Minimum Speed & $\mathrm{RPM}$ & 0.001 \\
\hline
\end{tabular}

Flow curve measurements were obtained using a concentric (Z41) cylindrical rotor. The design is shown in Table 1-6. The Z41rotor is initially installed onto the RS600 and a zero reference point is determined by the rheometer. The Z41 rotor is then removed. A homogenized sample is then placed into the appropriate cup and lowered into a temperature/controlled cup holder, which controlled the temperature at $25^{\circ} \mathrm{C}$. The RS600 rheometer can control the rate at which the rotor spins and measures both the rotational speed and the torque (the resistance to shear). The shear stress at the wall of the rotating rotor is then calculated (internally by the Haake 
software) based on the product of the measured torque and geometry (A-factor) of the rotor. The shear rate of the rotating rotor is calculated as the product of the measured speed and geometry (M-factor, assumes fluid is Newtonian) of the rotor. The A-factor, M-factor, shear rate range and the ramp up time, hold time at maximum shear rate, and ramp down time are provided in Table 1-6.

Table 1-6: Z41 Rotor Specifications and Ramp Rates

\begin{tabular}{|c|c|c|}
\hline Design of Rotor & \multicolumn{2}{|c|}{ Z41 Rotor } \\
\hline \multirow{10}{*}{$\begin{array}{l}\mathbf{R a} \\
\mathbf{R} \mathbf{I} \\
\end{array}$} & Rotor radius (mm) & $\mathrm{R}_{\mathrm{i}}=20.7$ \\
\hline & Cup Radius (mm) & $\mathrm{R}_{\mathrm{a}}=21.7$ \\
\hline & Height of rotor (mm) & $\mathrm{L}=55$ \\
\hline & Sample Volume $\left(\mathrm{cm}^{3}\right)$ & $\mathrm{V}=15$ \\
\hline & A factor $(\mathrm{Pa} /(\mathrm{N} \cdot \mathrm{m}))$ & 6750 \\
\hline & $M$ factor $\left(\mathrm{s}^{-1} /\left(\operatorname{rad} \cdot \mathrm{s}^{-1}\right)\right)$ & 22.40 \\
\hline & Measuring Range $\left(\mathrm{s}^{-1}\right)$ & $0-1000$ \\
\hline & Ramp up time (min) & 5 \\
\hline & Hold time (min) & 1 \\
\hline & Ramp down time (min) & 5 \\
\hline
\end{tabular}

Prior to performing any flow curve measurement, the rotor and cup are inspected for visual damage that could potentially impact the flow measurement. National Institute of Standards and Technology (NIST) traceable Newtonian oil standards were used to verify the operability of the RS600 at a measurement temperature of $25^{\circ} \mathrm{C}$. The viscosity of the NIST traceable Newtonian oil standards at $25^{\circ} \mathrm{C}$ is shown in Table 1-7. The flow curve for the NIST standard was analyzed as a Newtonian fluid and the calculated viscosity was compared to its NIST traceable Newtonian value. The rheometer is considered operable if the calculated viscosity is within $\pm 10 \%$ of the NIST traceable Newtonian oil standard viscosity as stated in Table 1-7. The measured viscosity of the NIST standard was $53.0 \mathrm{cP}$, well within the required range.

Table 1-7: Cole-Parmer NIST Traceable Newtonian Oil Standard

\begin{tabular}{|c|c|c|c|c|c||}
\hline \hline \multirow{2}{*}{$\begin{array}{c}\text { Standard } \\
\text { Type }\end{array}$} & \multicolumn{3}{|c|}{ Viscosity $(\mathrm{cP})$ at $25^{\circ} \mathrm{C}$} & \multirow{2}{*}{ Lot Number } & $\begin{array}{c}\text { Expiration } \\
\text { Date }\end{array}$ \\
\cline { 2 - 4 } & $-10 \%$ & Reported & $+10 \%$ & & $2 / 6 / 2006$ \\
\hline N35 & 46.34 & 51.49 & 56.64 & 130704 & 204 \\
\hline
\end{tabular}


For each sample that required rheology, two replicates were analyzed. A typical flow curve is shown in Figure 1-1. Inspection of this flow curve shows that the down curves were better defined at the lower shear rates and were slightly more viscous than the up curve, hence the down curves were selected as the curve to be analyzed for all samples. There is however, very little difference between the up and down curves.

Figure 1-1: Typical Kaolin/Sand Flow Curve of an SMP Sample

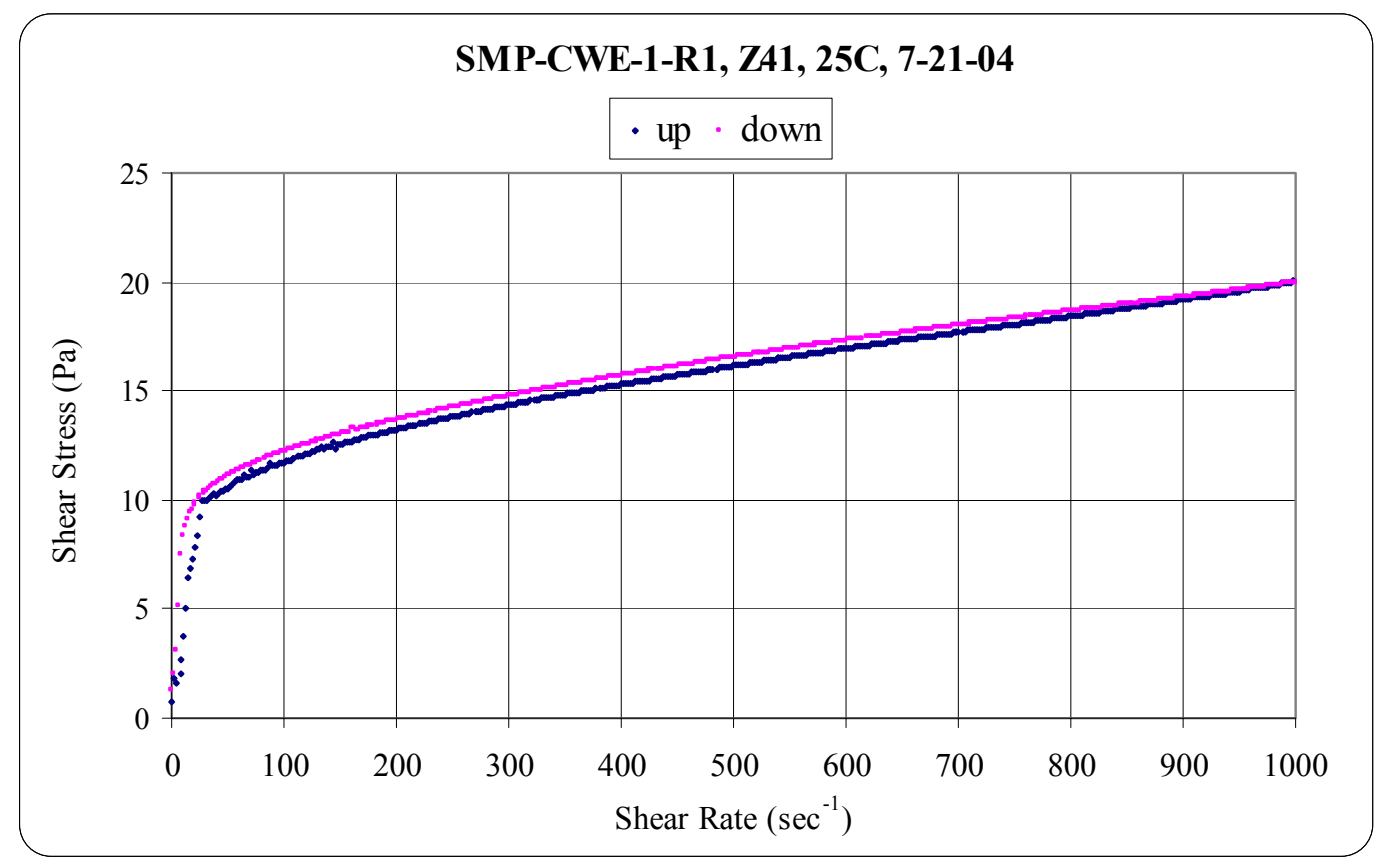

The down curves were analyzed as a Bingham Plastic fluid (equation 1-1) and the $1^{\text {st }}$ measurements are fitted with the Bingham Plastic curves and are shown in Appendix A. All the flow curves were fitted with the Bingham Plastic model between a shear rate of $100 \mathrm{sec}^{-1}$ to 1000 $\mathrm{sec}^{-1}$. The down curve results for the Bingham Plastic yield stress and consistency include the individual measurements, average and percent standard deviation, and are summarized in Table 1-8. Limits provided in the TAR as well as in the procurement specification ${ }^{3}$ for the Bingham Plastic parameters were 10 to 300 dynes $/ \mathrm{cm}^{2}$ for the yields stress and 3 to $50 \mathrm{cP}$ for the consistency. In all cases, the kaolin/sand slurry samples Bingham Plastic yield stresses and consistencies were below $50 \%$ of the maximum yield stress and consistency values.

$$
\tau=\tau_{B P}+\eta_{B P} \cdot \dot{\gamma}
$$

Where: $\tau=$ shear stress $\left(\right.$ dynes $\left./ \mathrm{cm}^{2}\right)\left\{\right.$ Note $1 \mathrm{~Pa}=10$ dynes $\left./ \mathrm{cm}^{2}\right)$

$\dot{\gamma}=$ shear rate $\left(\sec ^{-1}\right)$

$\tau_{\mathrm{BP}}=$ Bingham Plastic yield stress $\left(\right.$ dynes $\left./ \mathrm{cm}^{2}\right)$

$\eta_{\mathrm{BP}}=$ Bingham Plastic Viscosity (or consistency) $\{$ centipose $=\mathrm{cP}\}$ 
Table 1-8: Kaolin/Sand Bingham Plastic Rheological Data for the SMP

\begin{tabular}{|c|c|c|c|c|c|c|c|c|c|}
\hline \multirow{2}{*}{$\begin{array}{l}\text { Sample } \\
\text { location }\end{array}$} & \multirow{2}{*}{$\begin{array}{l}\text { Day } \\
\text { Pulled }\end{array}$} & \multicolumn{4}{|c|}{ Yield Stress (dynes $\left./ \mathrm{cm}^{2}\right)$} & \multicolumn{4}{|c|}{ Consistency (cP) } \\
\hline & & Sample 1 & Sample 2 & Average & $\begin{array}{c}\text { \% standard } \\
\text { deviation }\end{array}$ & Sample 1 & Sample 2 & Average & $\begin{array}{c}\% \text { standard } \\
\text { deviation }\end{array}$ \\
\hline \multirow{7}{*}{ SMP-CWE } & 1 & 122.4 & 121.7 & 122.0 & $0.38 \%$ & 8.09 & 7.98 & 8.04 & $0.95 \%$ \\
\hline & 2 & 108.6 & 107.1 & 107.9 & $0.97 \%$ & 7.58 & 7.46 & 7.52 & $1.07 \%$ \\
\hline & 3 & 108.7 & 106.6 & 107.6 & $1.37 \%$ & 7.47 & 7.38 & 7.43 & $0.80 \%$ \\
\hline & 4 & 108.6 & 109.8 & 109.2 & $0.73 \%$ & 7.39 & 7.45 & 7.42 & $0.52 \%$ \\
\hline & 5 & 95.4 & 95.9 & 95.6 & $0.39 \%$ & 6.85 & 6.87 & 6.86 & $0.28 \%$ \\
\hline & 6 & 99.0 & 99.0 & 99.0 & $0.02 \%$ & 7.04 & 7.01 & 7.03 & $0.34 \%$ \\
\hline & 7 & 98.8 & 96.9 & 97.9 & $1.42 \%$ & 7.07 & 6.99 & 7.03 & $0.81 \%$ \\
\hline \multirow{3}{*}{ SMP-ECR } & 3 & 103.6 & 105.1 & 104.3 & $1.05 \%$ & 7.11 & 7.31 & 7.21 & $1.96 \%$ \\
\hline & 6 & 83.6 & 83.0 & 83.3 & $0.55 \%$ & 6.41 & 6.38 & 6.39 & $0.32 \%$ \\
\hline & 7 & 96.1 & 97.3 & 96.7 & $0.87 \%$ & 6.96 & 7.00 & 6.98 & $0.38 \%$ \\
\hline
\end{tabular}

This data reveals that the samples pulled on the same day from the CWE are more viscous when compared to the ECR samples. This is supported by the wt\% TS and density data, were the CWE results are greater than that of the ECR results, indicating that the rheology should be more viscous for the CWE sample. The relationship between density, yield stress and consistency with that of wt\% TS for the CWE and ECR samples is very linear between the wt $\%$ TS range tested here (22 to 25\% wt\% TS) and is shown in Figure 1-2, Figure 1-3, and Figure 1-4. These figures shows that SMP slurry samples pulled from the CWE and ECR locations are very similar in nature, given a wt $\%$ TS. Hence there were no additional physical analysis of the samples for wt $\% \mathrm{TS}$, density or rheology.

Figure 1-2: Density Versus Wt\% TS For SMP

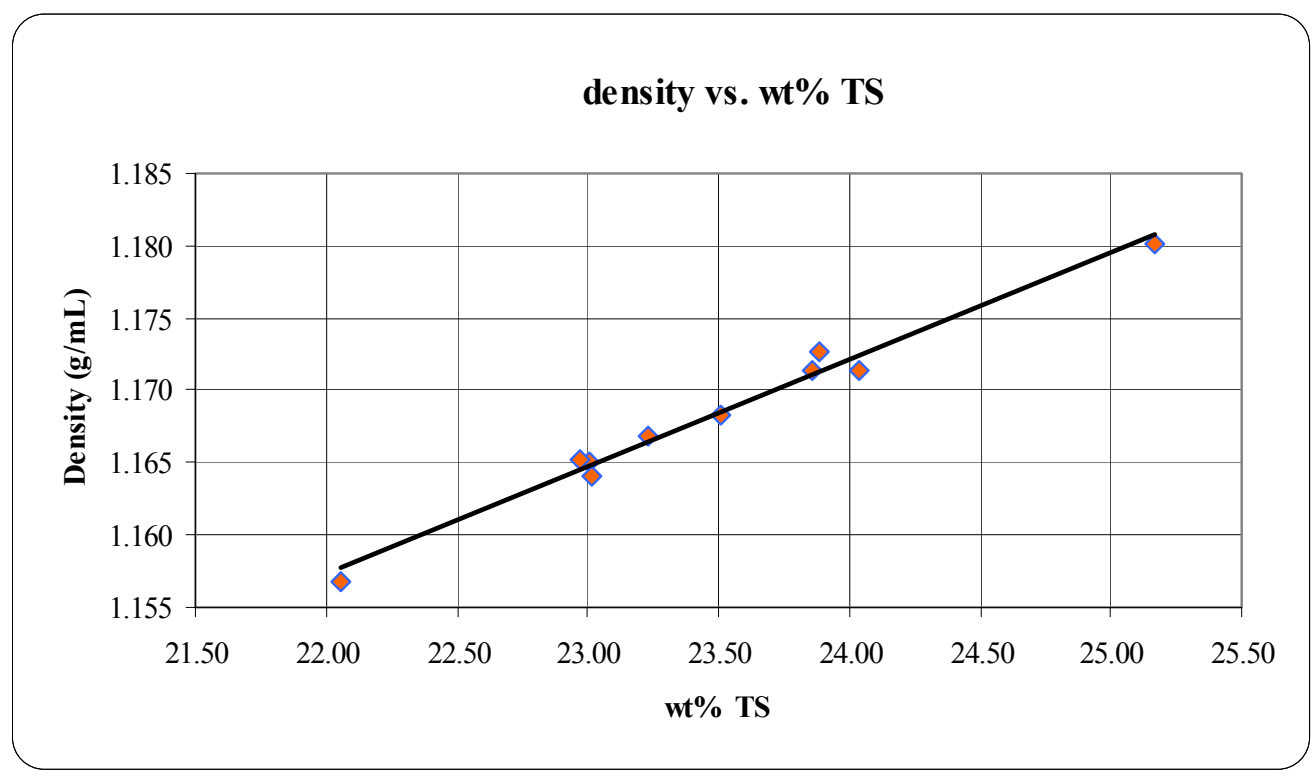


Figure 1-3: Bingham Plastic Yield Stress Versus Wt\% TS For SMP

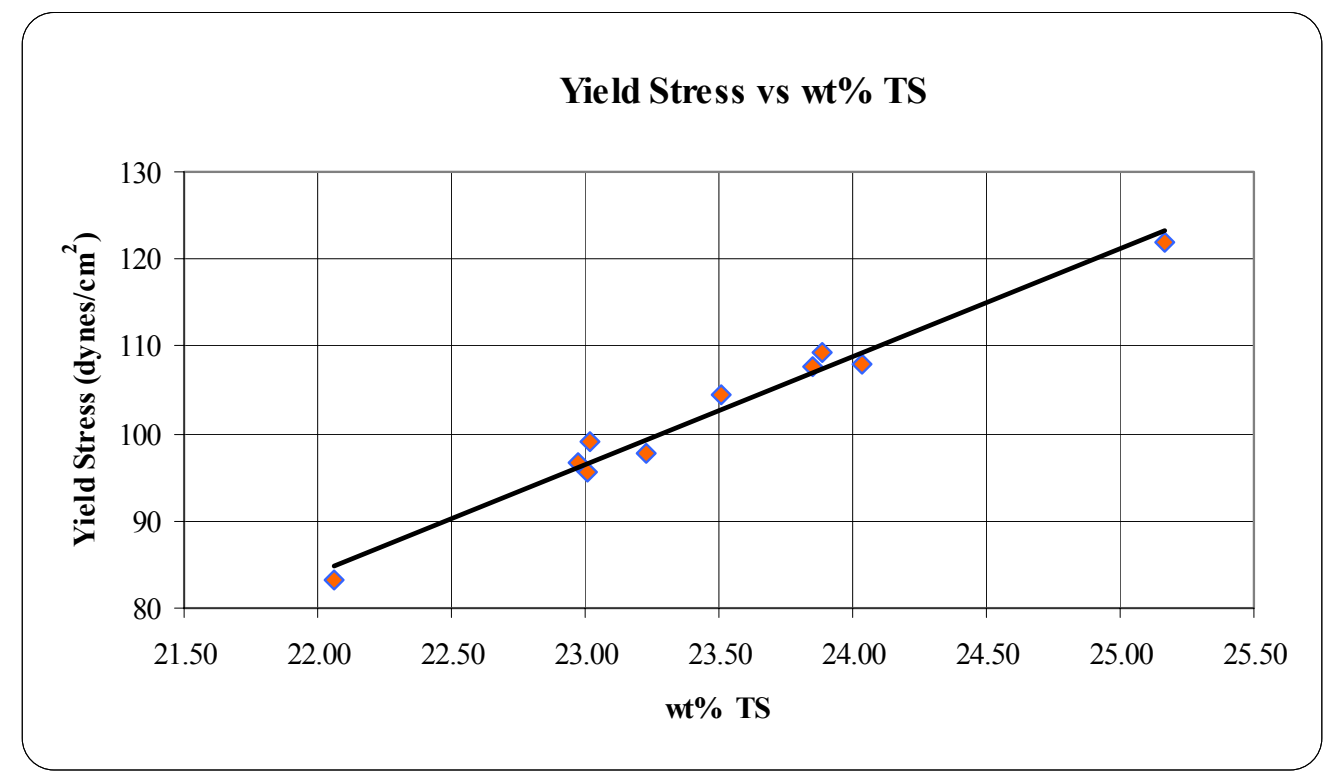

Figure 1-4: Bingham Plastic Consistency Versus Wt\% TS For SMP

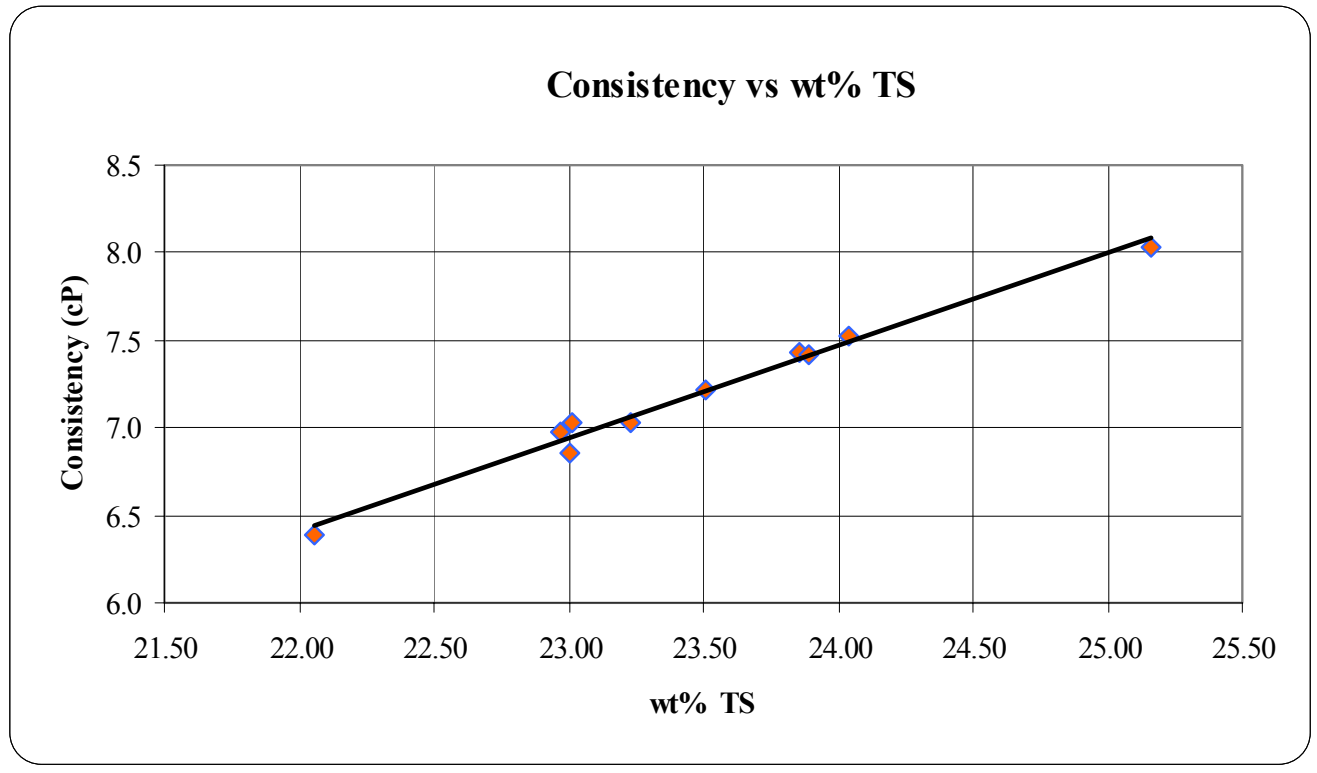

\subsection{Particle Size Distribution}

Appendix C contains selected technical data of the B-100 dry kaolin used in the SMP tests. The $2^{\text {nd }}$ page of this appendix contains the particle size distribution (PSD), on an oxide mass basis, which indicates that 98 percent of the kaolin is smaller than 20 microns and 42 percent smaller than 0.5 microns. The results are summarized in Table 1-9. 


\section{Table 1-9: Unimin B-100 Kaolin PSD - Percent Weight on Oxide Basis}

\begin{tabular}{|c|c|c|c||}
\hline Bin & Size (microns) & \% in Bin & \% Cummulative \\
\hline 1 & $\geq 20$ & 2 & 100 \\
\hline 2 & $10 \leq \mathrm{x}<20$ & 6 & 98 \\
\hline 3 & $5 \leq \mathrm{x}<10$ & 9 & 92 \\
\hline 4 & $2 \leq \mathrm{x}<5$ & 16 & 83 \\
\hline 5 & $1 \leq \mathrm{x}<2$ & 11 & 67 \\
\hline 6 & $0.5 \leq \mathrm{x}<1$ & 14 & 56 \\
\hline 7 & $\mathrm{x}<0.5$ & 42 & 42 \\
\hline
\end{tabular}

The sand used during the SMP testing was an aggregate $\mathbf{5}^{\mathbf{5}}$ used for masonry mortar. The nominal particle size distribution provided in the ASTM specification, for either natural or manufactured sand is shown in Table 1-10.

Table 1-10: ASTM Specification for Aggregate (Sand) Used in SMP Test

\begin{tabular}{||c|c|c|c||}
\hline \multicolumn{2}{|c|}{ Sieve Size } & \multicolumn{2}{c|}{ Percent Passing } \\
\cline { 3 - 4 } & No. 4 & Natural Sand & Manufactured Sand \\
\hline $4.75-\mathrm{mm}$ & No. 8 & 95 to 100 & 100 \\
\hline $2.36-\mathrm{mm}$ & 70 to 100 & 95 to 100 \\
\hline $1.18-\mathrm{mm}$ & No. 16 & 40 to 75 & 40 to 100 \\
\hline $600-\mu \mathrm{m}$ & No. 30 & 10 to 35 & 20 to 75 \\
\hline $300-\mu \mathrm{m}$ & No. 50 & 2 to 15 & 10 to 25 \\
\hline $150-\mu \mathrm{m}$ & No. 100 & 0 to 5 & 0 to 10 \\
\hline $75-\mu \mathrm{m}$ & No. 200 & \multicolumn{2}{|c}{} \\
\hline
\end{tabular}

A sample of the sand that was provided to SRNL was dried and the PSD was determined using an ATM Sonic Sifter, which utilizes ASTM sieves. The sonic sifter uses both vibration and pulsing to sieve the material through the selected ASTM sieves. The sieves used and results are provided in Table 1-11. Table 1-10 and Table 1-11 clearly show that the sand particles are much larger than that of the B-100 kaolin.

\footnotetext{
${ }^{5}$ ASTM C144-03, "Standard Specification For Aggregate for Masonry Mortar”, 2003
} 
Table 1-11: PSD of Aggregate (Sand) Provided to SRNL

\begin{tabular}{|c|c|c|c|c|c|c|}
\hline \multicolumn{2}{|c|}{ Sieves } & \multicolumn{4}{c|}{ Sample } & \multirow{2}{*}{ Average } \\
\hline Sieve Size & Micron & $\# 1$ & $\# 2$ & $\# 3$ & $\# 4$ & \\
\hline $425 \mu \mathrm{m}$ & $\mathrm{x} \geq 425$ & $39.13 \%$ & $33.31 \%$ & $40.90 \%$ & $31.16 \%$ & $36.13 \%$ \\
\hline $250 \mu \mathrm{m}$ & $425>\mathrm{x} \geq 250$ & $40.00 \%$ & $39.54 \%$ & $39.84 \%$ & $38.91 \%$ & $39.57 \%$ \\
\hline $180 \mu \mathrm{m}$ & $250>\mathrm{x} \geq 180$ & $12.69 \%$ & $16.31 \%$ & $12.36 \%$ & $15.64 \%$ & $14.25 \%$ \\
\hline $125 \mu \mathrm{m}$ & $180>\mathrm{x} \geq 125$ & $6.24 \%$ & $7.65 \%$ & $5.50 \%$ & $9.81 \%$ & $7.30 \%$ \\
\hline $75 \mu \mathrm{m}$ & $125>\mathrm{x} \geq 75$ & $1.61 \%$ & $2.63 \%$ & $1.25 \%$ & $3.65 \%$ & $2.28 \%$ \\
\hline $45 \mu \mathrm{m}$ & $75>\mathrm{x} \geq 45$ & $0.20 \%$ & $0.41 \%$ & $0.11 \%$ & $0.62 \%$ & $0.33 \%$ \\
\hline Fines Collector & $\mathrm{x}<45$ & $0.13 \%$ & $0.14 \%$ & $0.04 \%$ & $0.22 \%$ & $0.13 \%$ \\
\hline
\end{tabular}

A Microtrac S-3000 particle size analyzer was used to measure the PSD of the kaolin/sand samples. Prior to analyzing the sample, the kaolin/sand samples were diluted using DI water. The S-3000 particle size analyzer measures the particle diameters by measuring the scattered light from a laser beam projected through a stream of the fluid carrying the diluted sample. The amount and direction of the light scattered by the particles is measured by an optical detector array and then analyzed to determine the size distribution of the particles. The S-3000 measuring range is between 0.026 to $1408 \mu \mathrm{m}$ and is functional checked using NIST traceable particle size standards. The sample is run three times and the values averaged. The particle size distribution, both volume (would be mass basis if only one type of material is being tested or if the different materials all have the same density) and number are provide in Appendix D for the requested data in Table 1-1. The mean volume and number diameters are provided in Table 1-12. The mean number diameters are fairly constant, stating that there are a lot of small particles, most likely from the kaolin. There are slight variations between the mean volume diameter and this is due to a large particle being measured (large particles can easily shift this distribution). It is hard to determine if the sand used in the slurry degraded to a smaller PSD due to pumping or if the larger sand particles settled out of the slurry and are laying on the bottom of the tank. There were no specifications for particle size in either the TAR or the SMP procurement specification. 
Table 1-12: Mean Volume and Number Particle Size Diameters for SMP Samples

\begin{tabular}{|c|c|c|c|}
\hline Sample location & $\begin{array}{c}\text { Day } \\
\text { Pulled }\end{array}$ & $\begin{array}{l}\text { Mean volume } \\
(\mathrm{mm})\end{array}$ & $\begin{array}{c}\text { Mean Number } \\
(\mathrm{mm})\end{array}$ \\
\hline \multirow{7}{*}{ SMP-CWE } & 1 & $\mathrm{~N} / \mathrm{M}$ & $\mathrm{N} / \mathrm{M}$ \\
\hline & 2 & $\mathrm{~N} / \mathrm{M}$ & $\mathrm{N} / \mathrm{M}$ \\
\hline & 3 & $\mathrm{~N} / \mathrm{M}$ & $\mathrm{N} / \mathrm{M}$ \\
\hline & 4 & 6.709 & 0.651 \\
\hline & 5 & $\mathrm{~N} / \mathrm{M}$ & $\mathrm{N} / \mathrm{M}$ \\
\hline & 6 & $\mathrm{~N} / \mathrm{M}$ & $\mathrm{N} / \mathrm{M}$ \\
\hline & 7 & 9.475 & 0.626 \\
\hline \multirow{7}{*}{ SMP-FFF } & 1 & $\mathrm{~N} / \mathrm{M}$ & $\mathrm{N} / \mathrm{M}$ \\
\hline & 2 & $\mathrm{~N} / \mathrm{M}$ & $\mathrm{N} / \mathrm{M}$ \\
\hline & 3 & $\mathrm{~N} / \mathrm{M}$ & $\mathrm{N} / \mathrm{M}$ \\
\hline & 4 & 6.799 & 0.639 \\
\hline & 5 & $\mathrm{~N} / \mathrm{M}$ & $\mathrm{N} / \mathrm{M}$ \\
\hline & 6 & $\mathrm{~N} / \mathrm{M}$ & $\mathrm{N} / \mathrm{M}$ \\
\hline & 7 & 12.50 & 0.622 \\
\hline \multirow{3}{*}{ SMP-ECR } & 3 & 5.876 & 0.625 \\
\hline & 6 & 14.02 & 0.622 \\
\hline & 7 & 6.374 & 0.654 \\
\hline
\end{tabular}

\subsection{REFERENCE}

WSRC-NB-2004-00122, Laboratory Notebook, “TNX Physical Properties of Kaolin” 
Revision 0

\section{APPENDIX A. $1^{\text {ST }}$ SAMPLE DOWN FLOW CURVES FITTED TO BINGHAM PLASTIC MODEL}


Figure A - 1: Down Flow Curve Sample SMP-CWE-1, Run 1

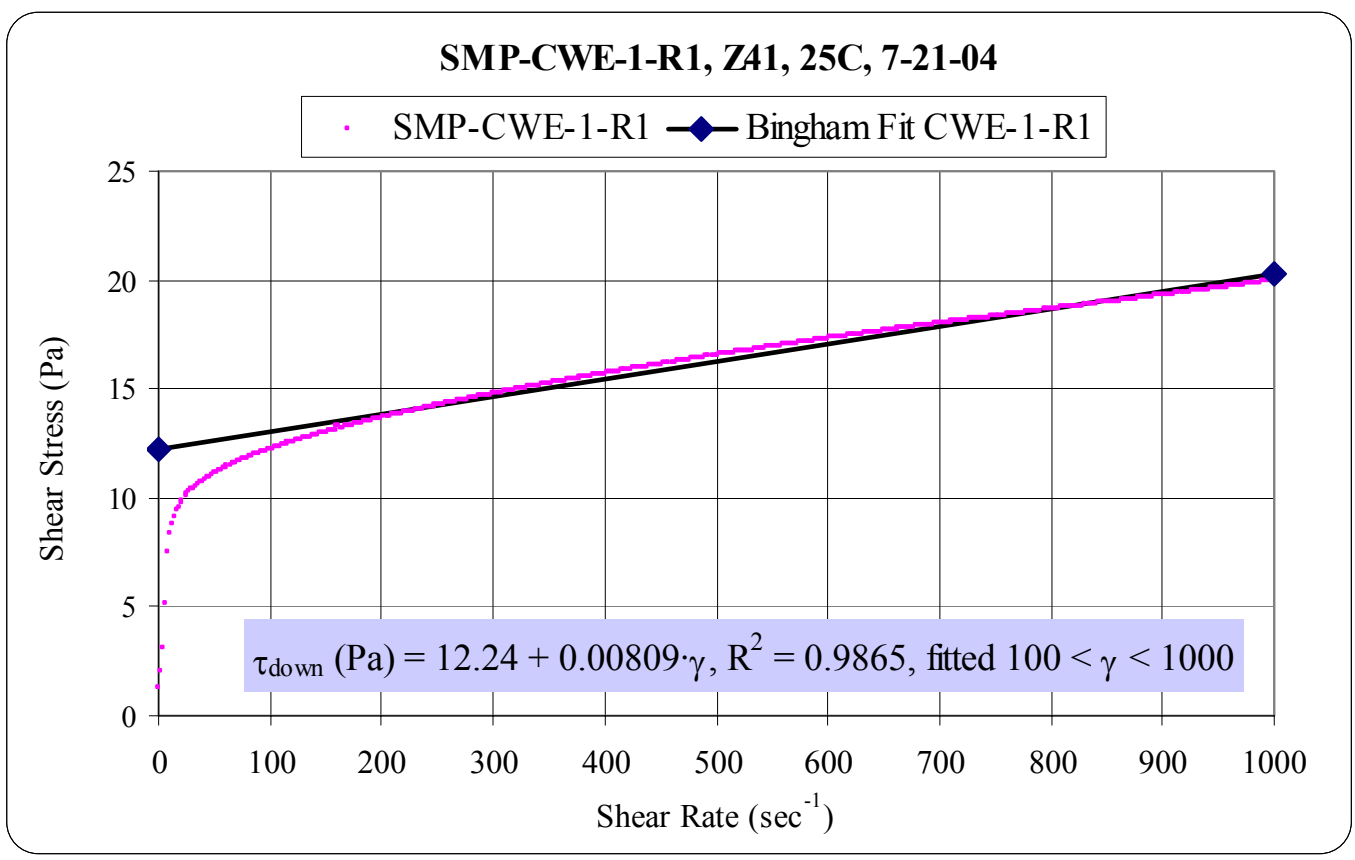

Figure A - 2: Down Flow Curve Sample SMP-CWE-2, Run 1

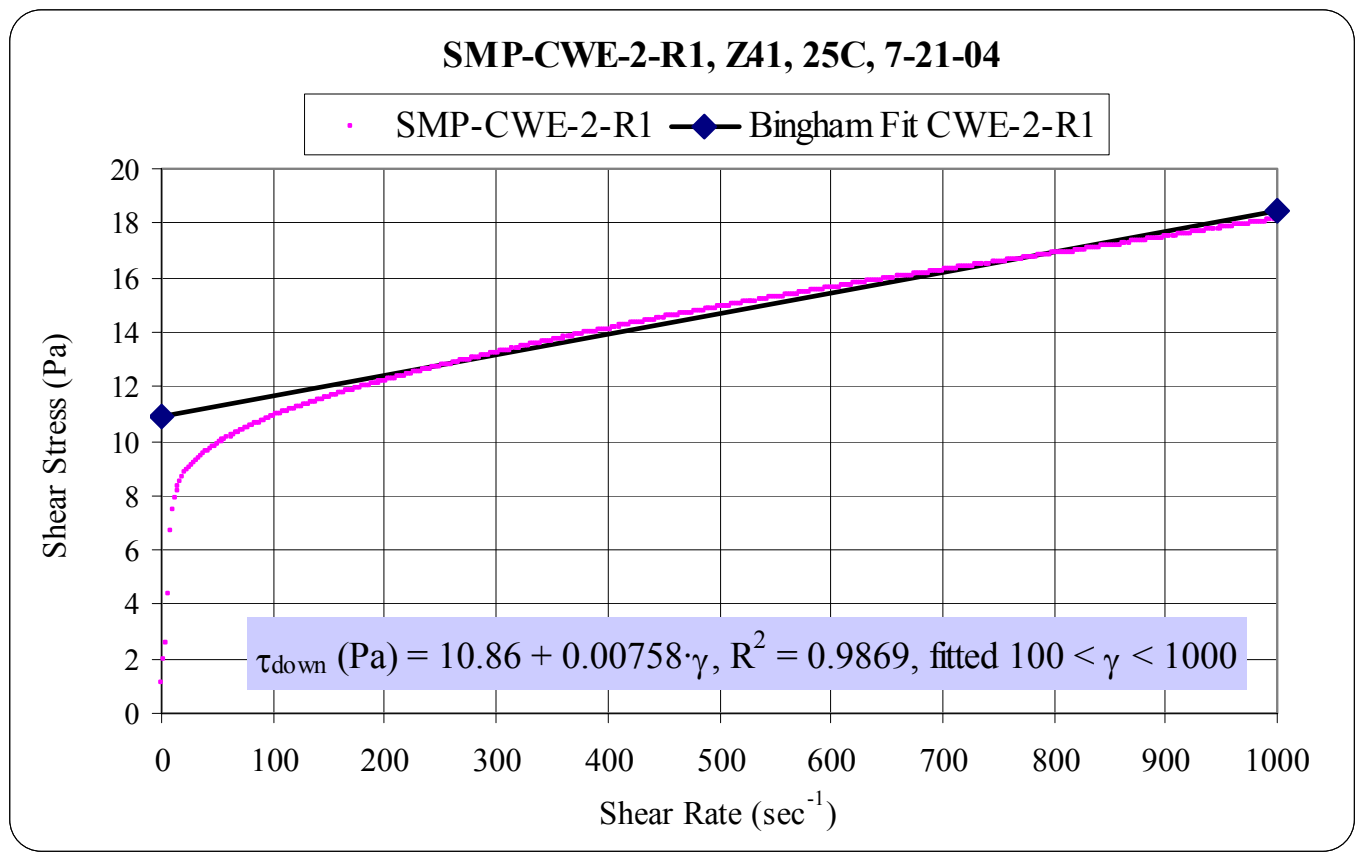


Figure A - 3: Down Flow Curve Sample SMP-CWE-3, Run 1

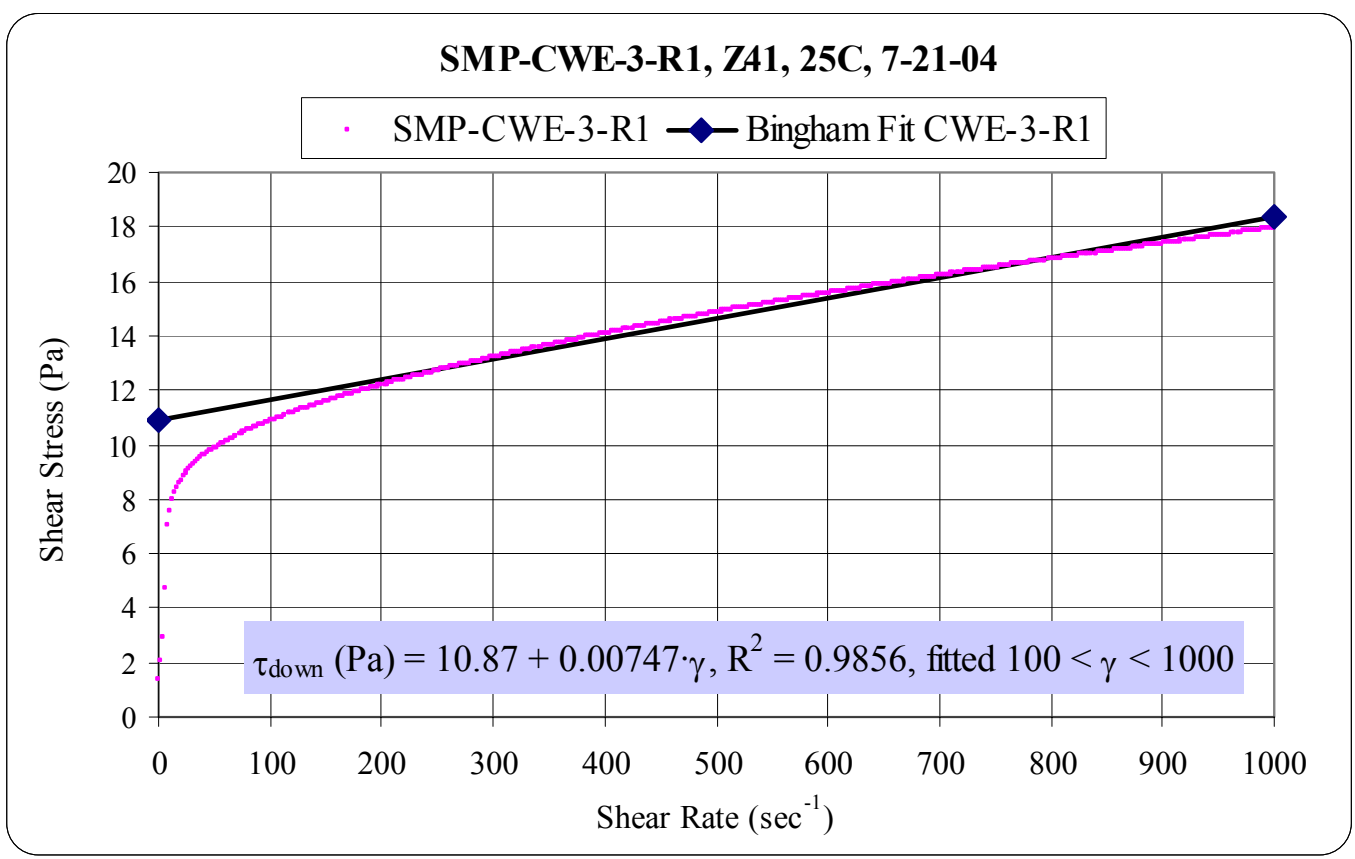

Figure A - 4: Down Flow Curve Sample SMP-CWE-4, Run 1

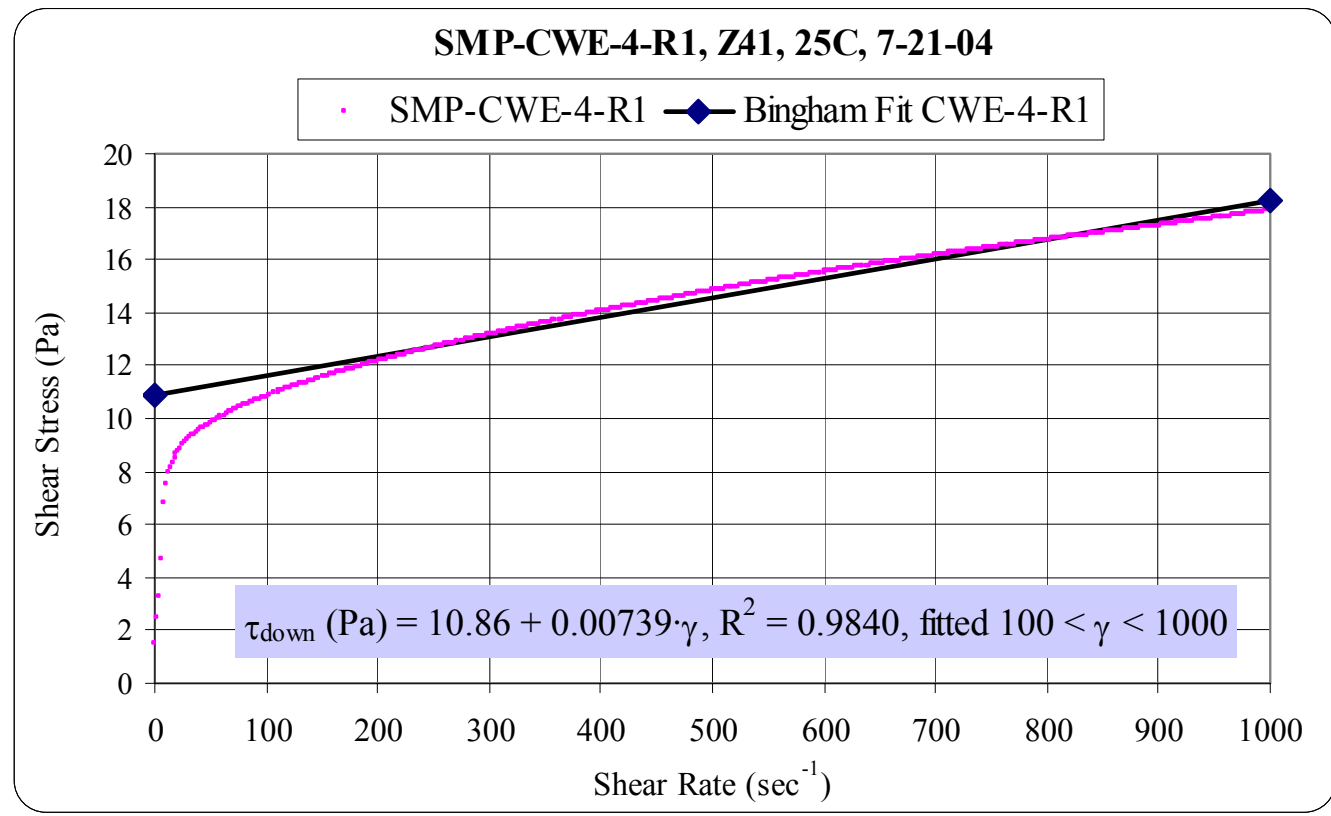


Figure A - 5: Down Flow Curve Sample SMP-CWE-5, Run 1

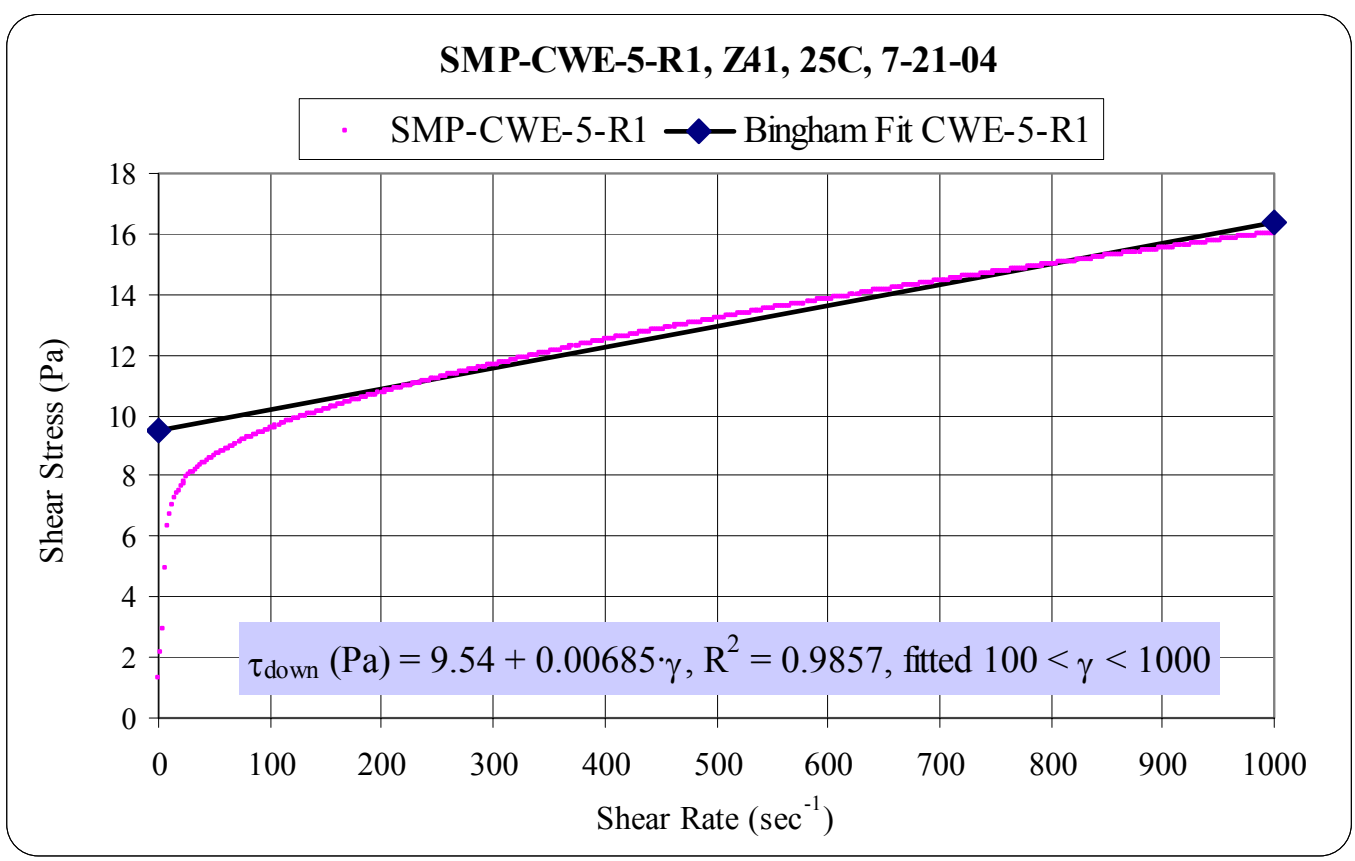

Figure A - 6: Down Flow Curve Sample SMP-CWE-6, Run 1

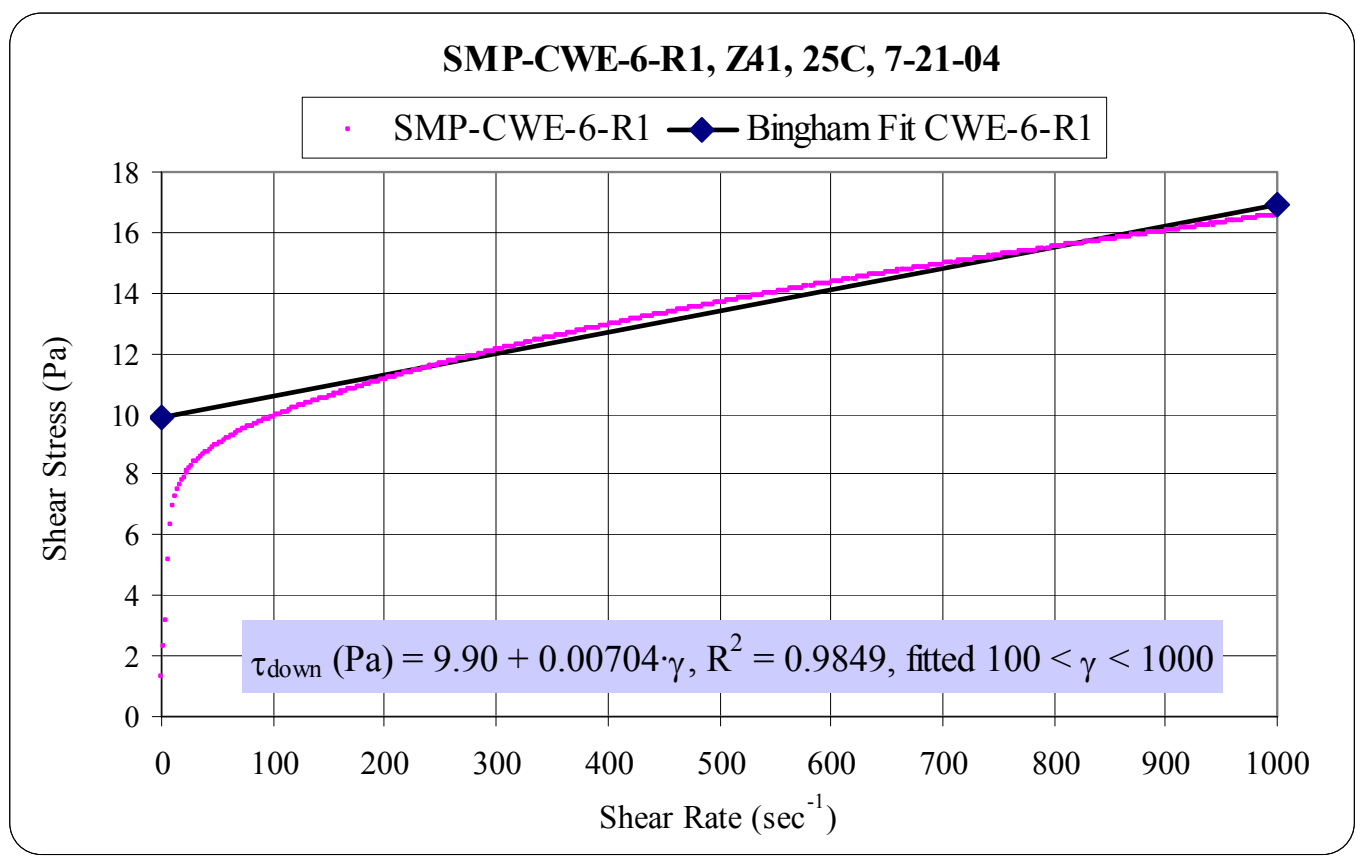


Figure A - 7: Down Flow Curve Sample SMP-CWE-7, Run 1

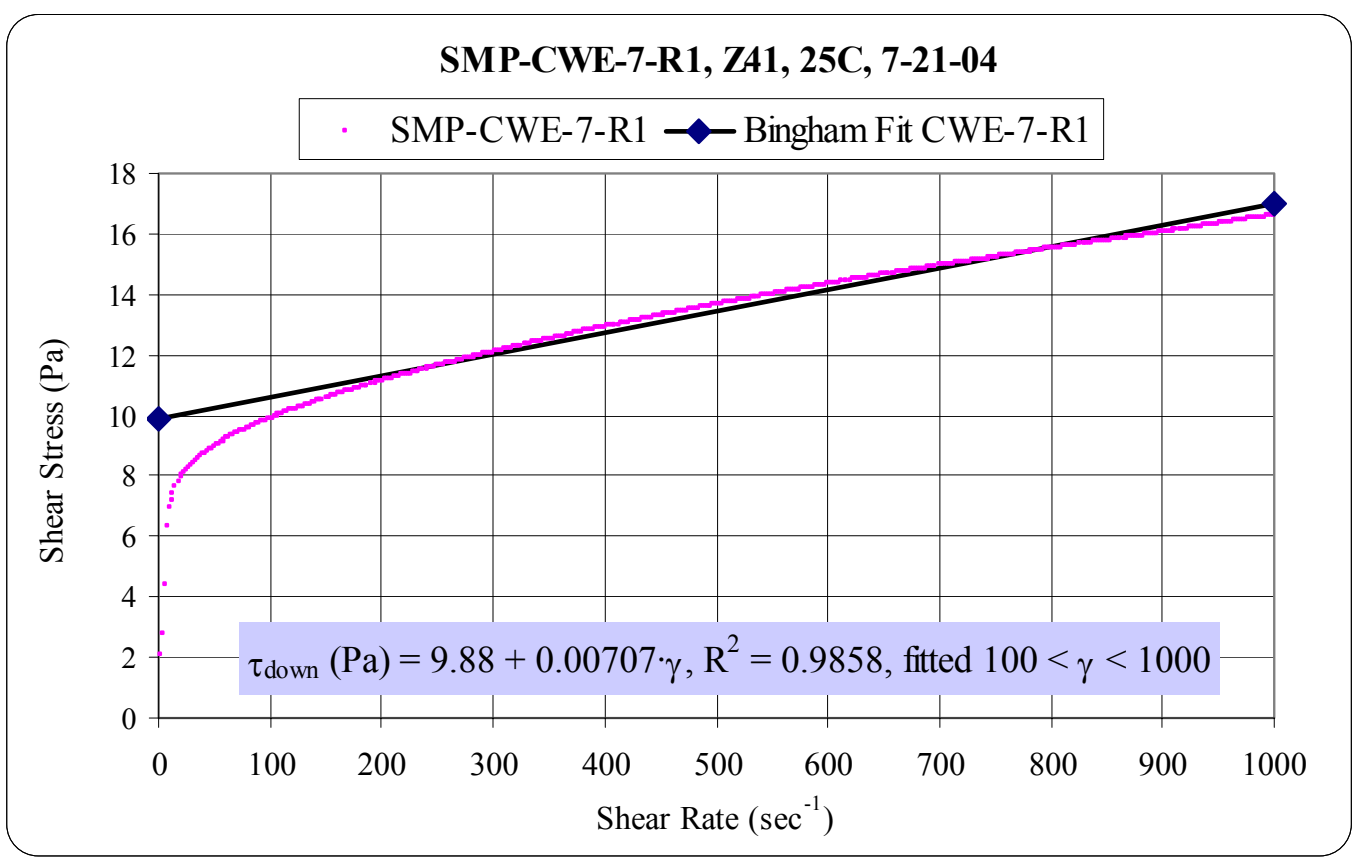

Figure A - 8: Down Flow Curve Sample SMP-ECR-3, Run 1

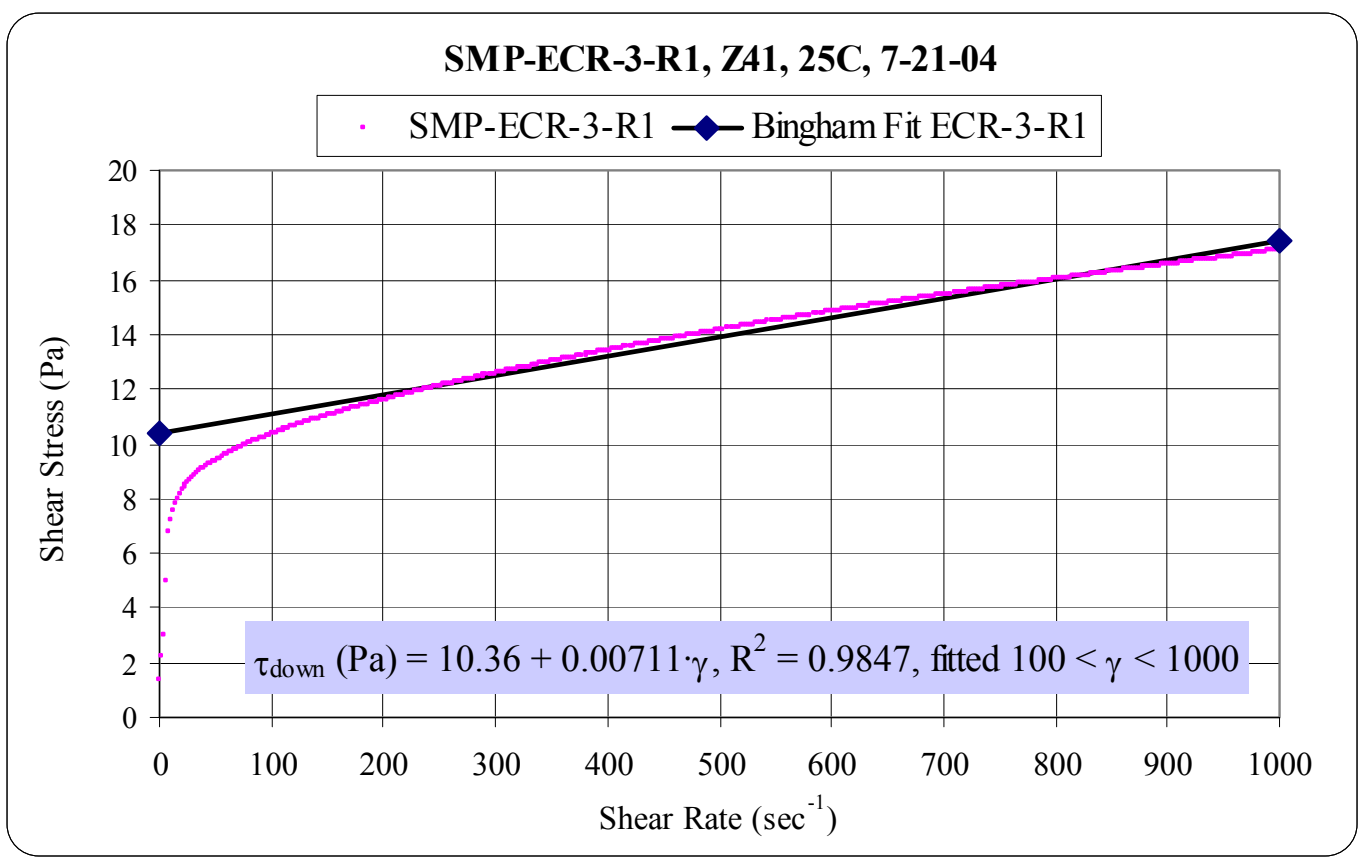


Figure A - 9: Down Flow Curve Sample SMP-CWE-6, Run 1

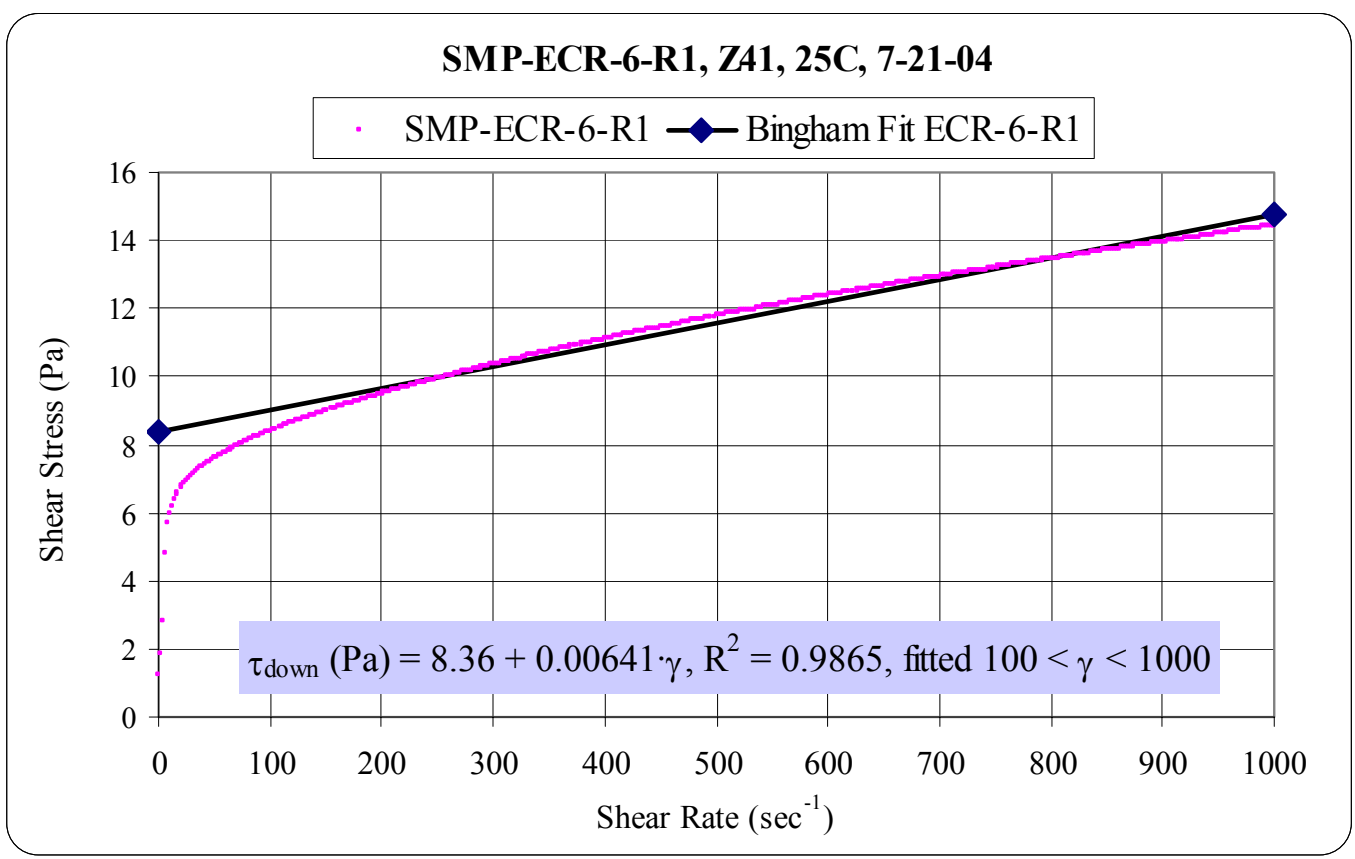

Figure A - 10: Down Flow Curve Sample SMP-CWE-3, Run 1

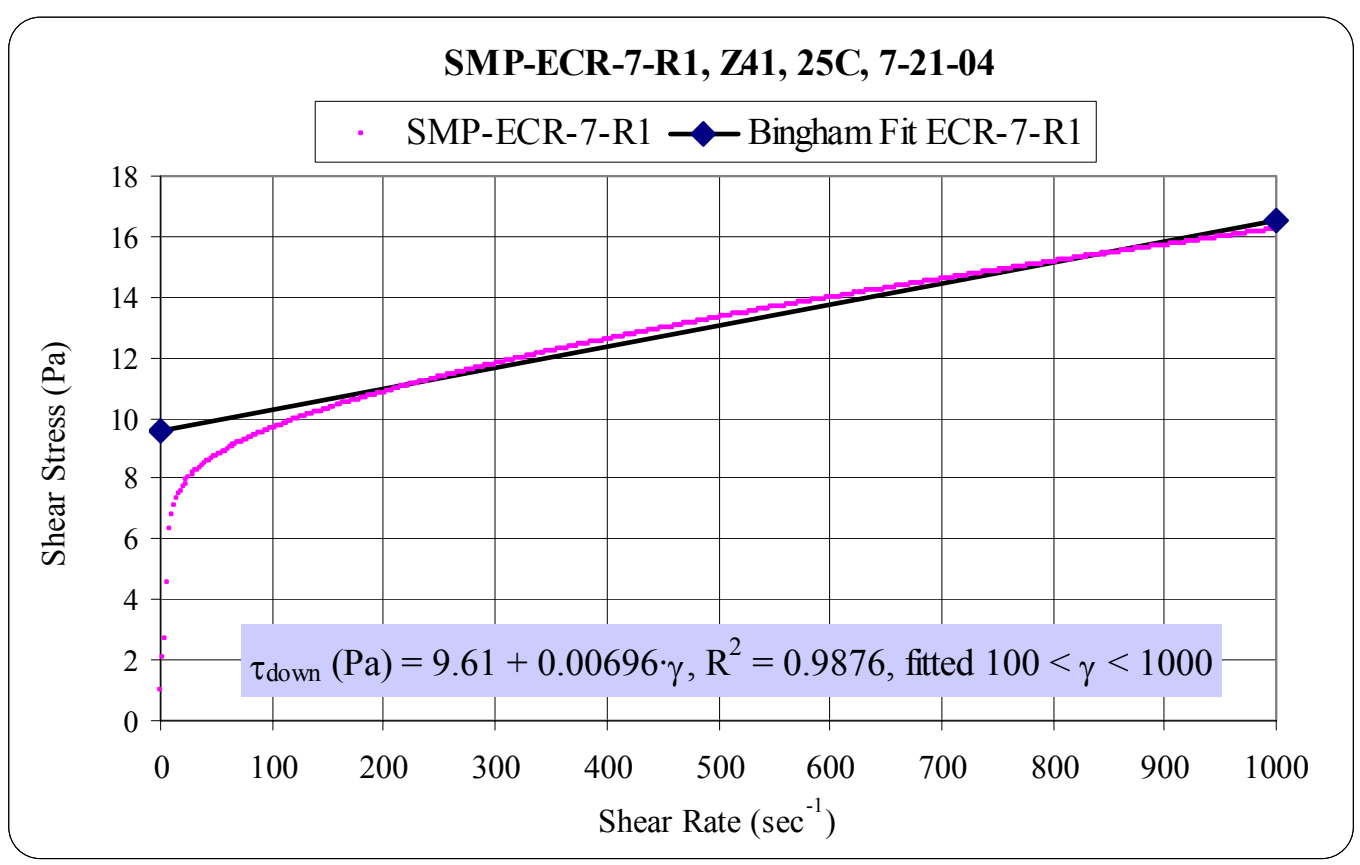


WSRC-TR-2004-00401

Revision 0

\section{APPENDIX B. PARTICLE SIZE DISTRIBUTUION}




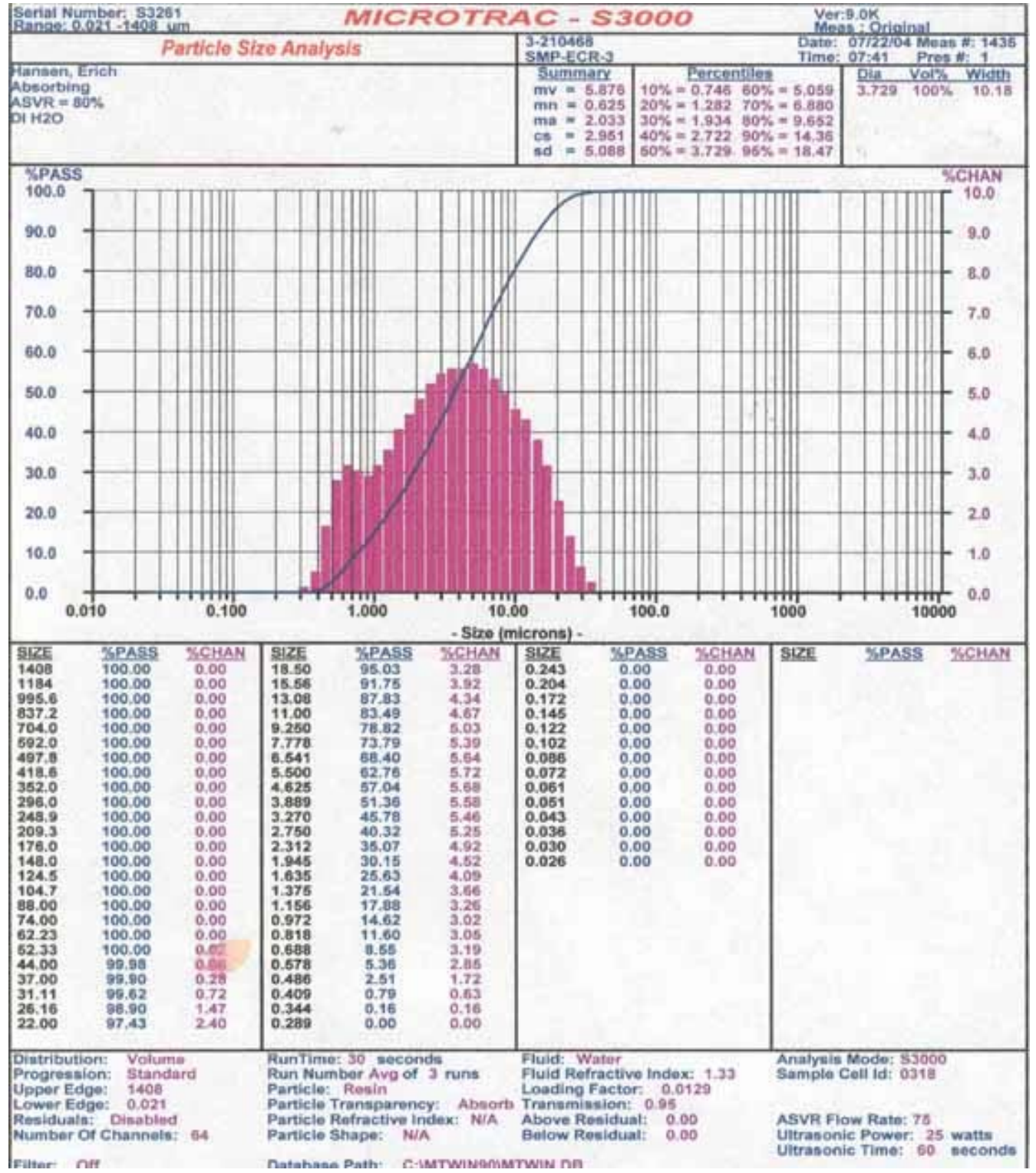

Figure B - 1: SMP-ECR-3 Volume Distribution 


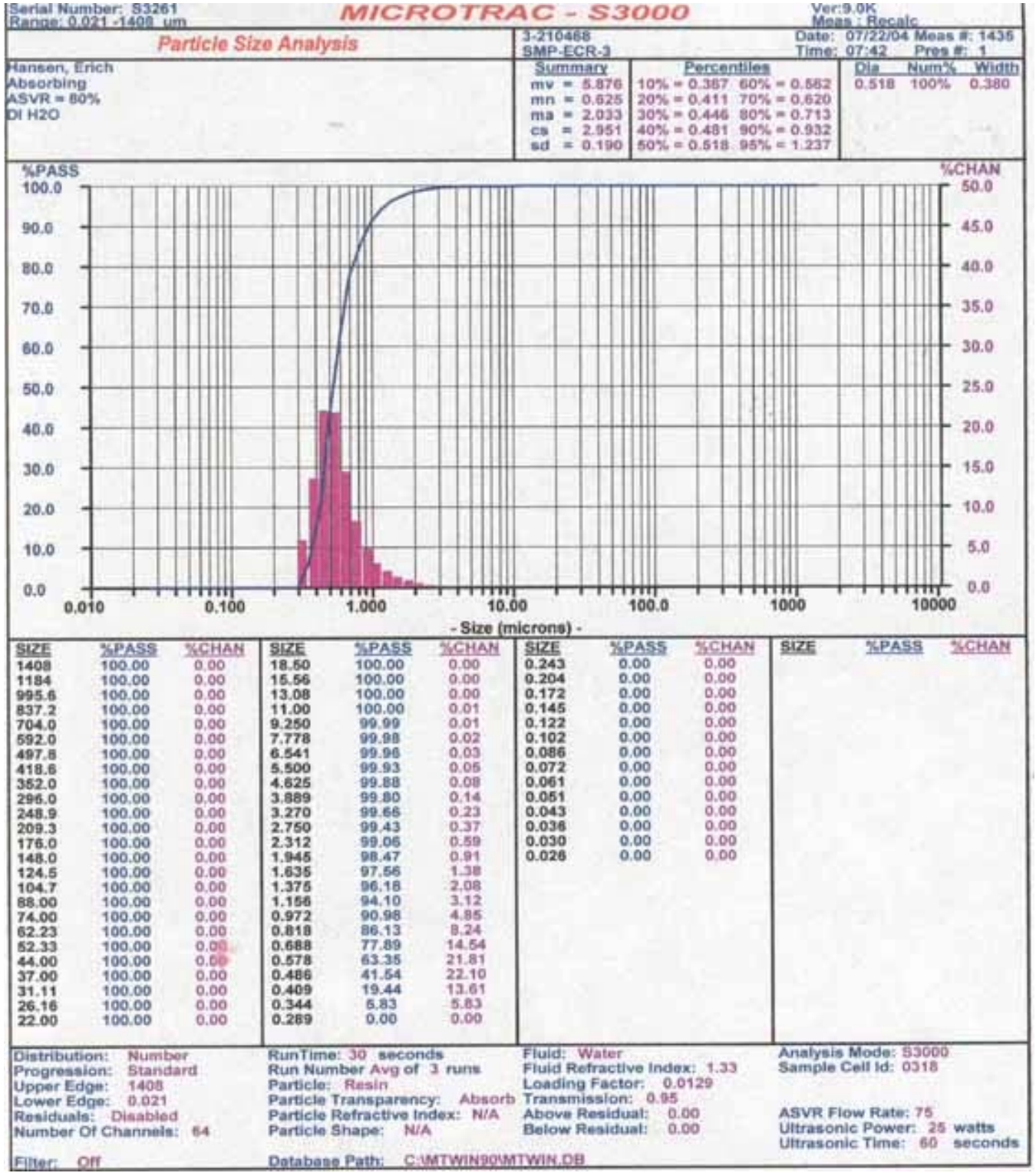

Figure B - 2: SMP-ECR-3 Number Distribution 


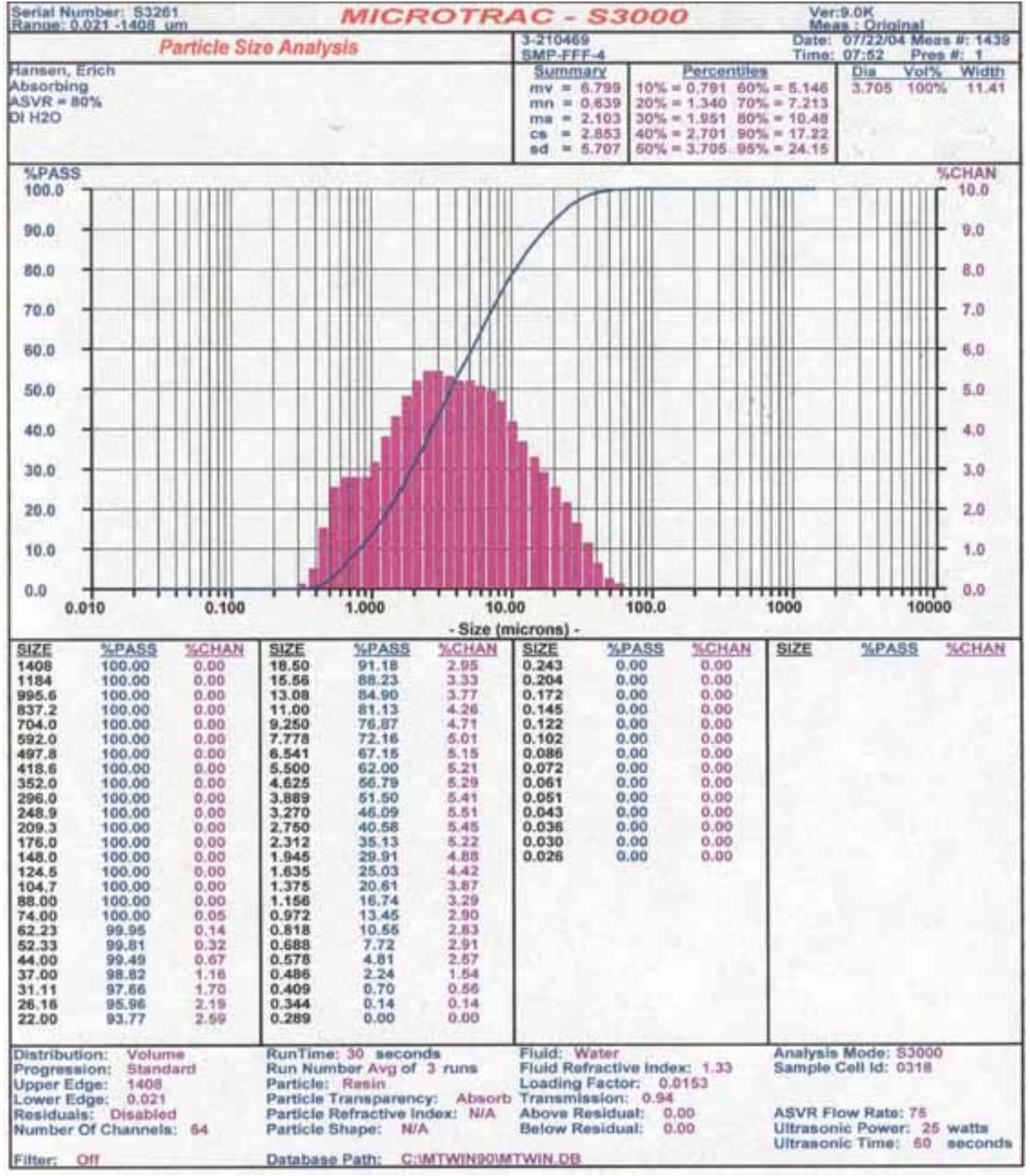

Figure B - 3: SMP-FFF-4 Volume Distribution 


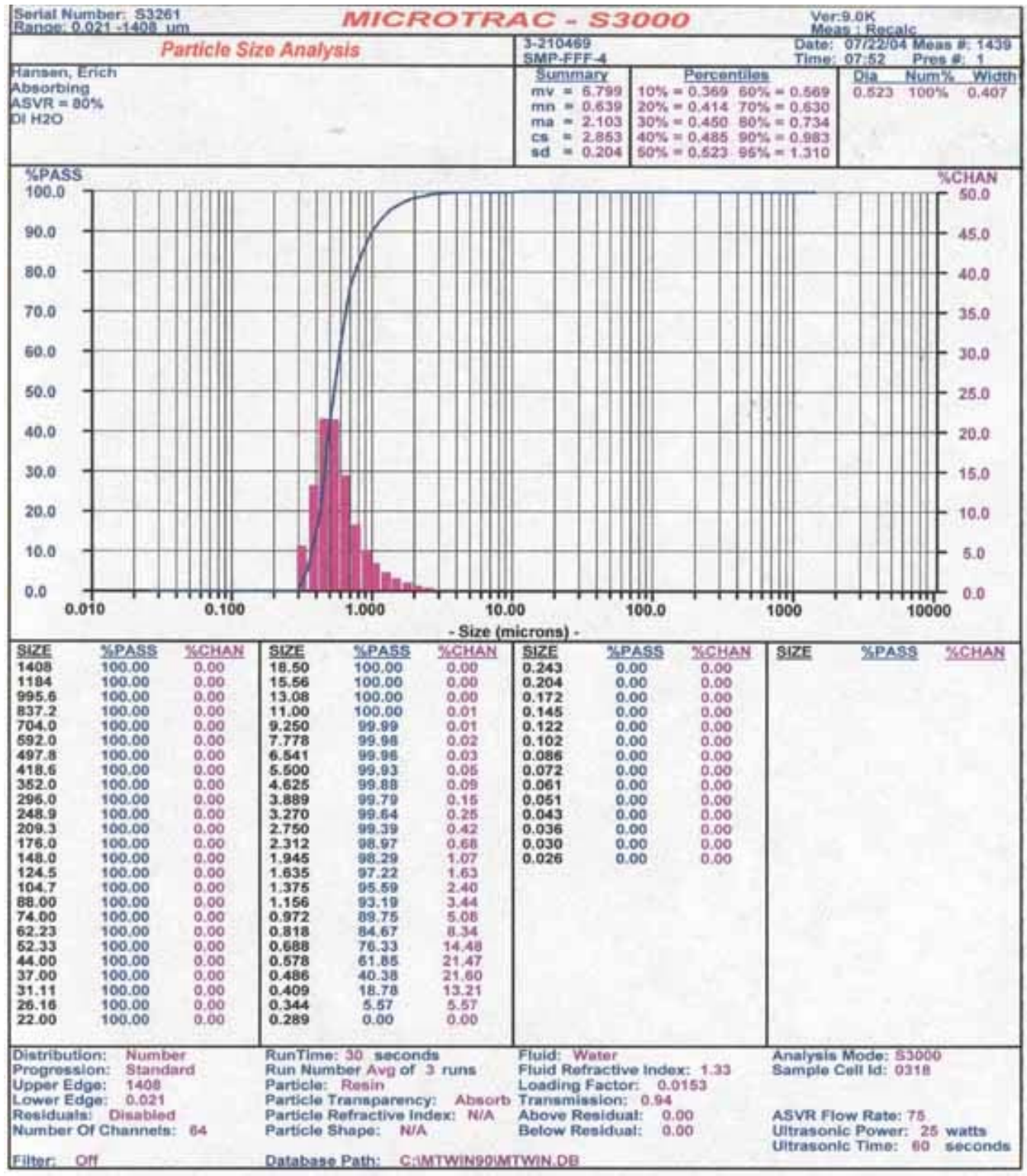

Figure B - 4: SMP-FFF-4 Number Distribution 


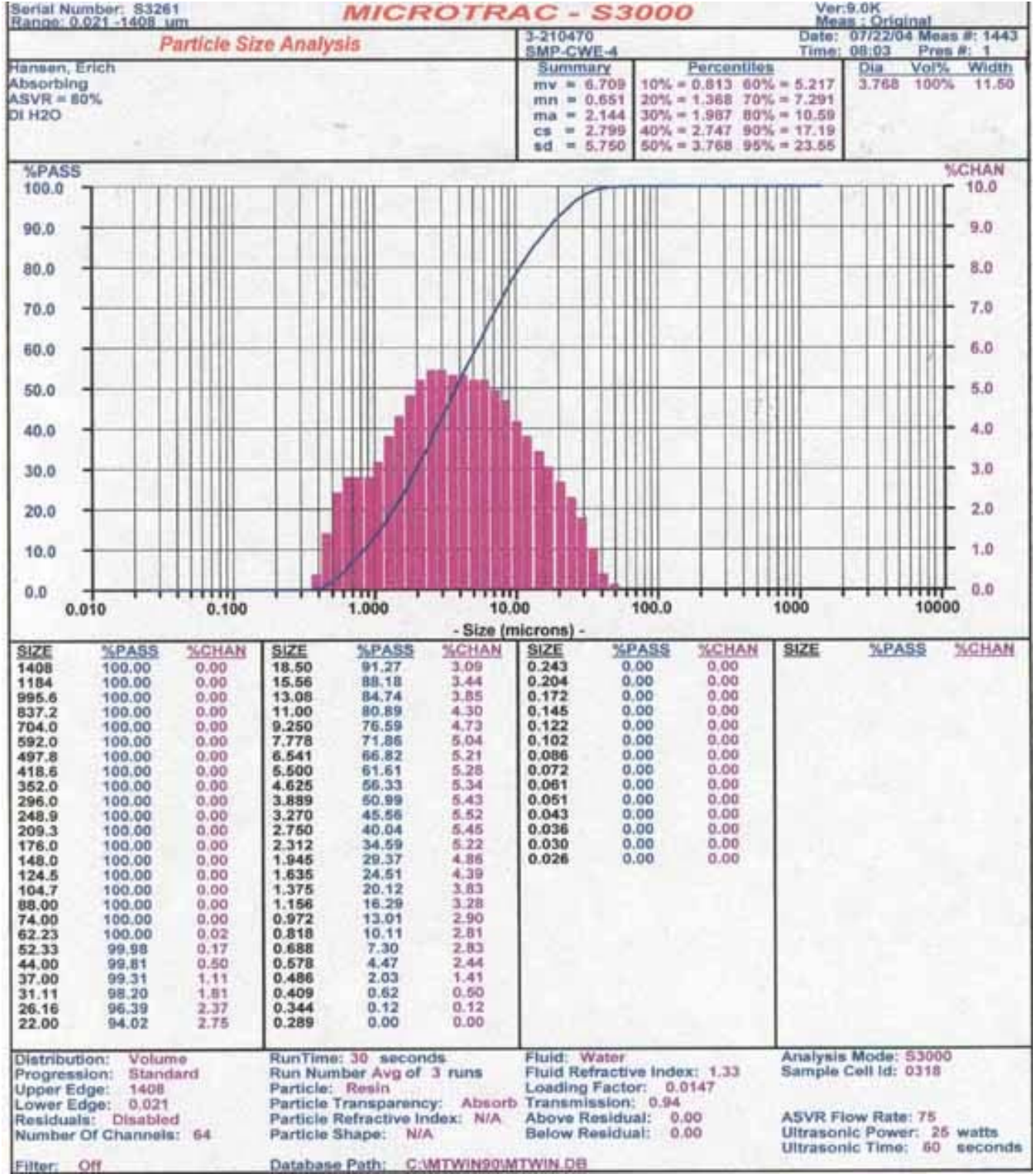

Figure B - 5: SMP-CWE-4 Volume Distribution 


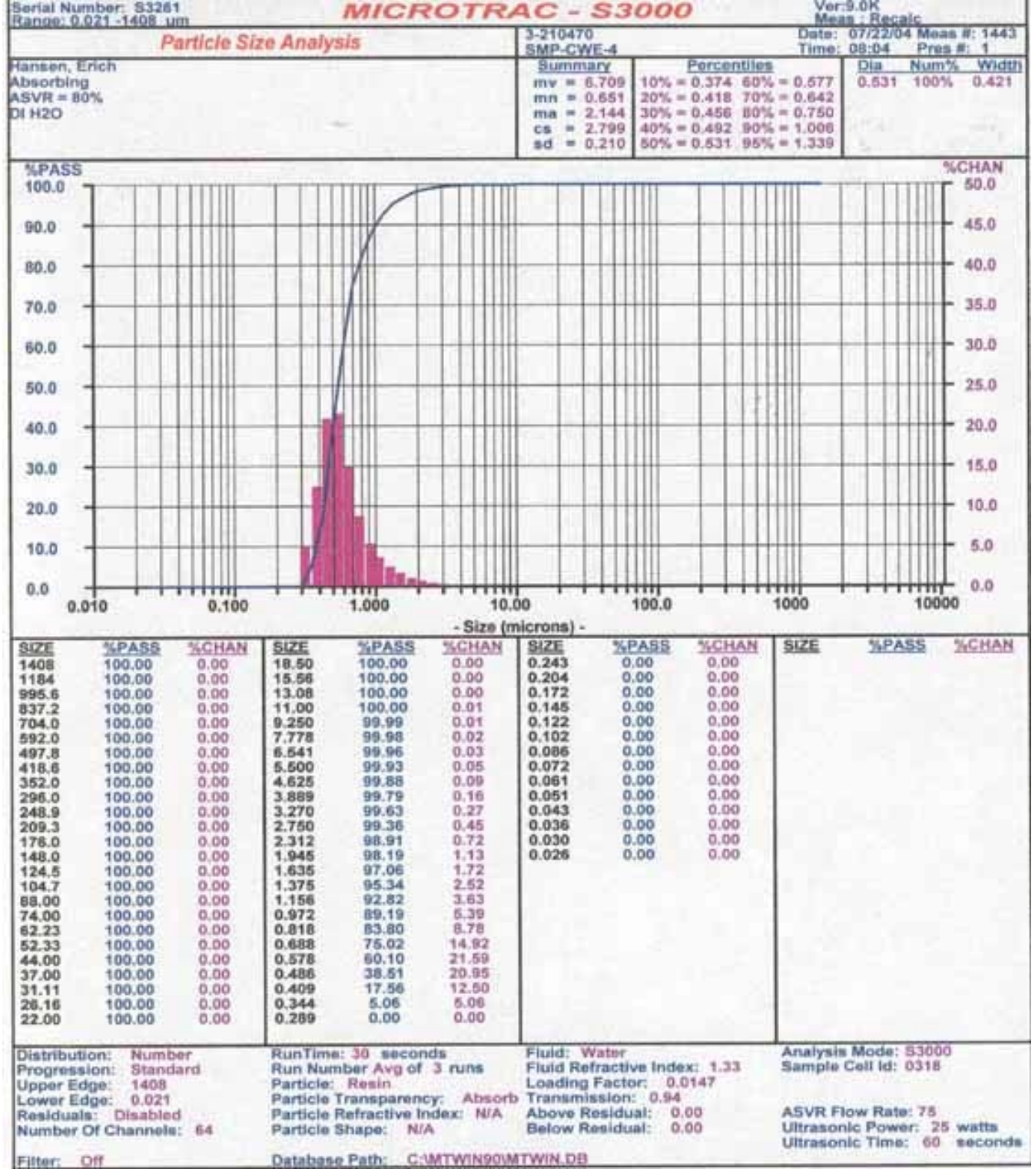

Figure B - 6: SMP-CWE-4 Number Distribution 


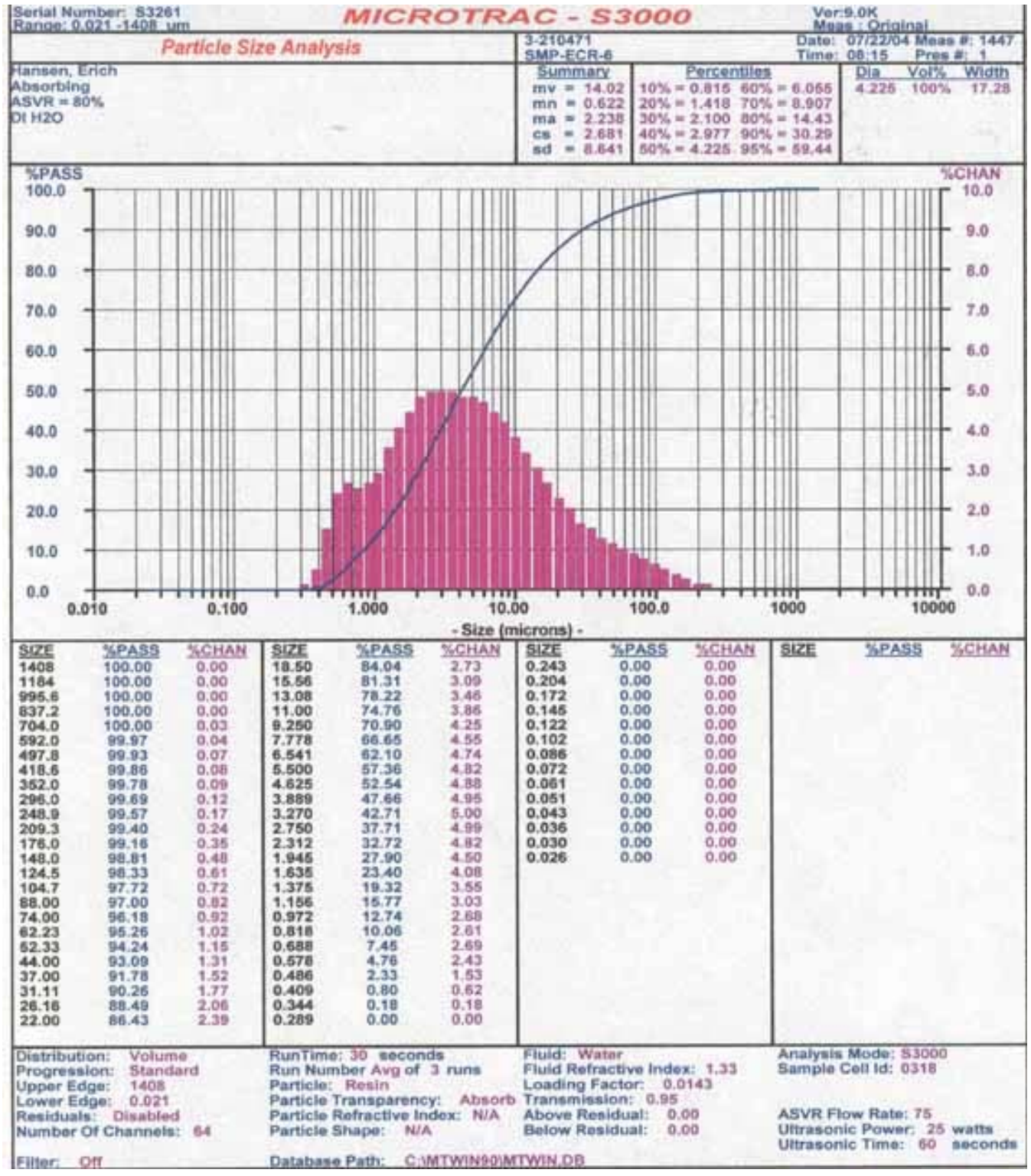

Figure B - 7: SMP-ECR-6 Volume Distribution 


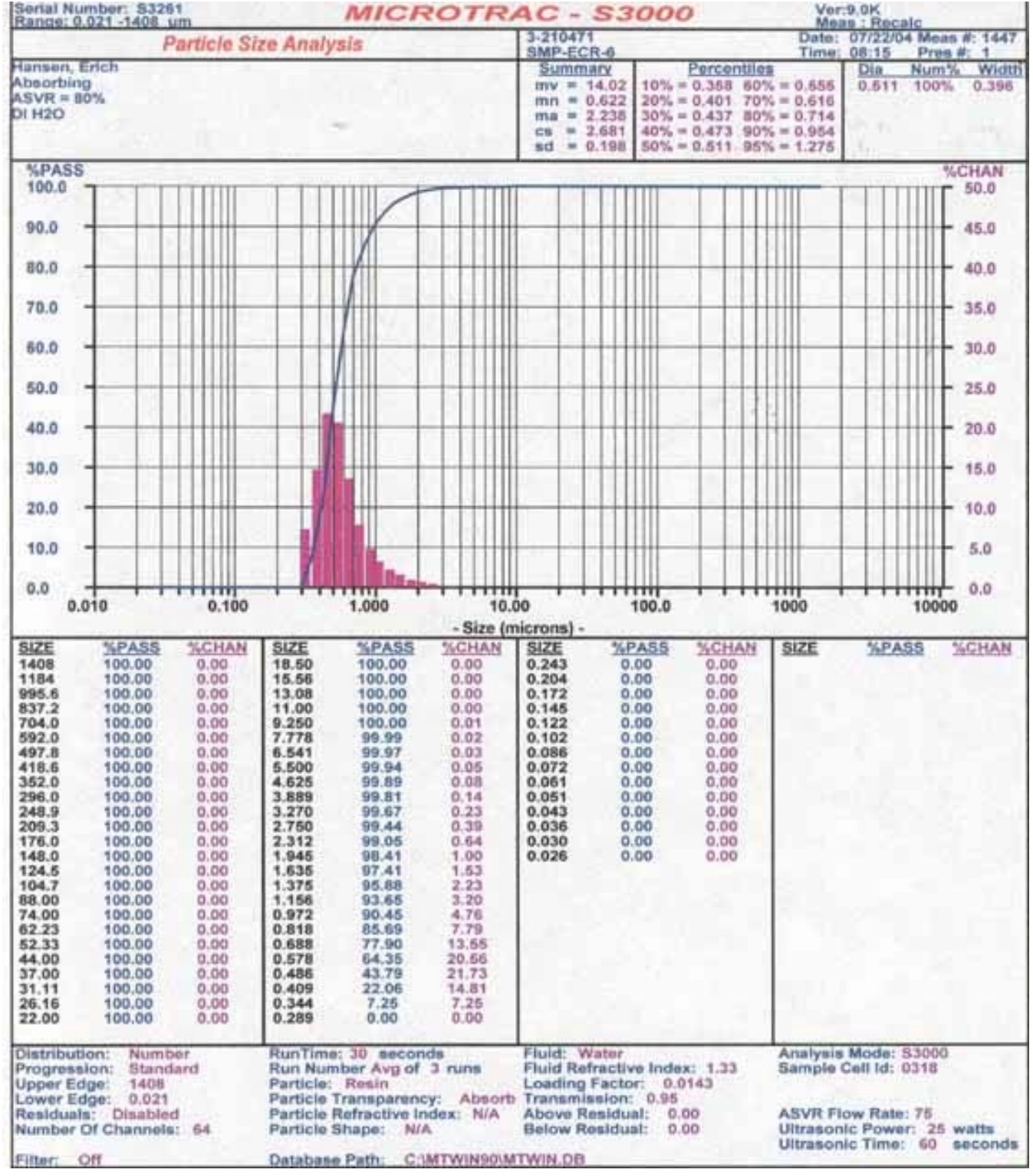

Figure B - 8: SMP-ECR-6 Number Distribution 


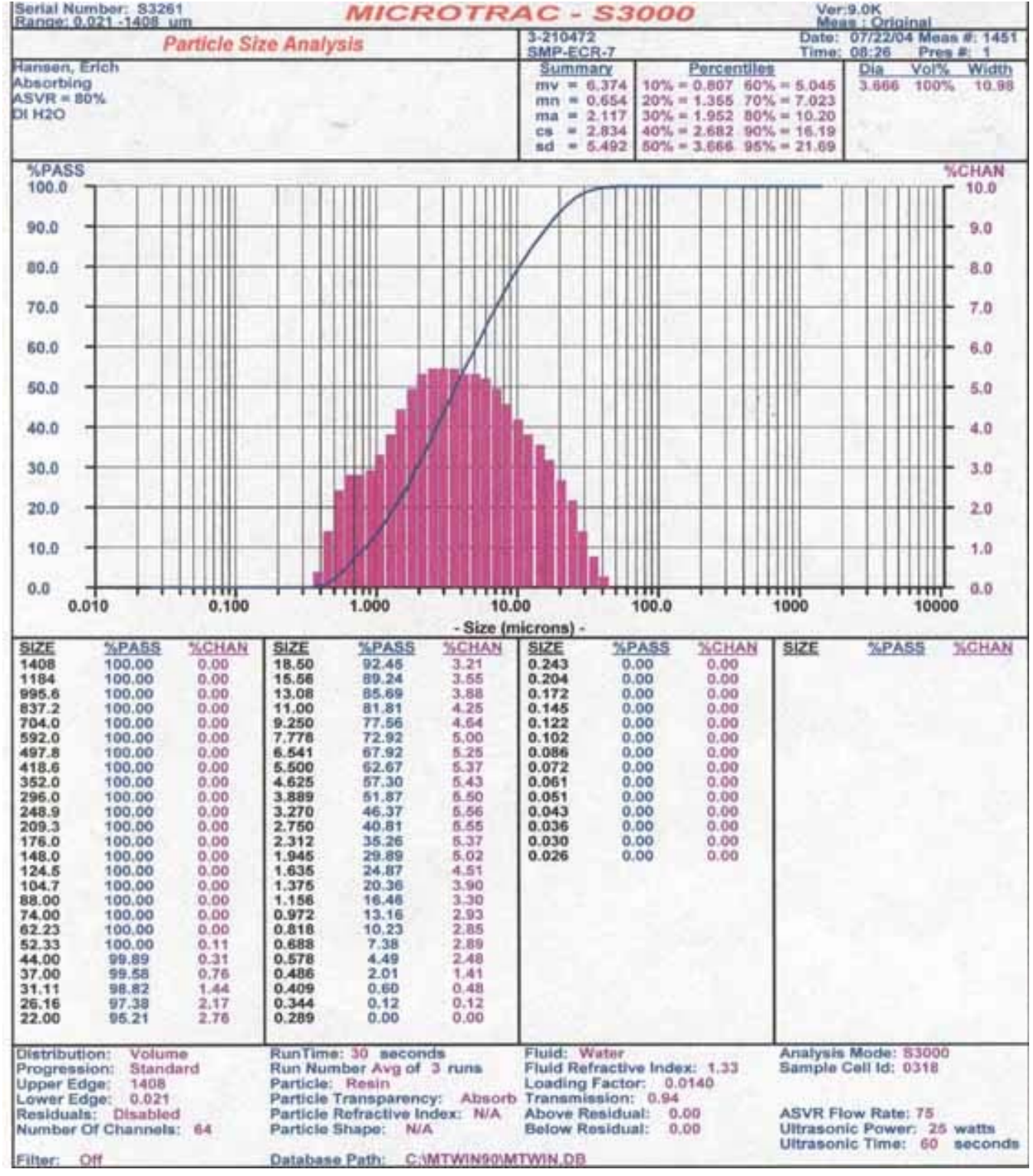

Figure B - 9: SMP-ECR-7 Volume Distribution 


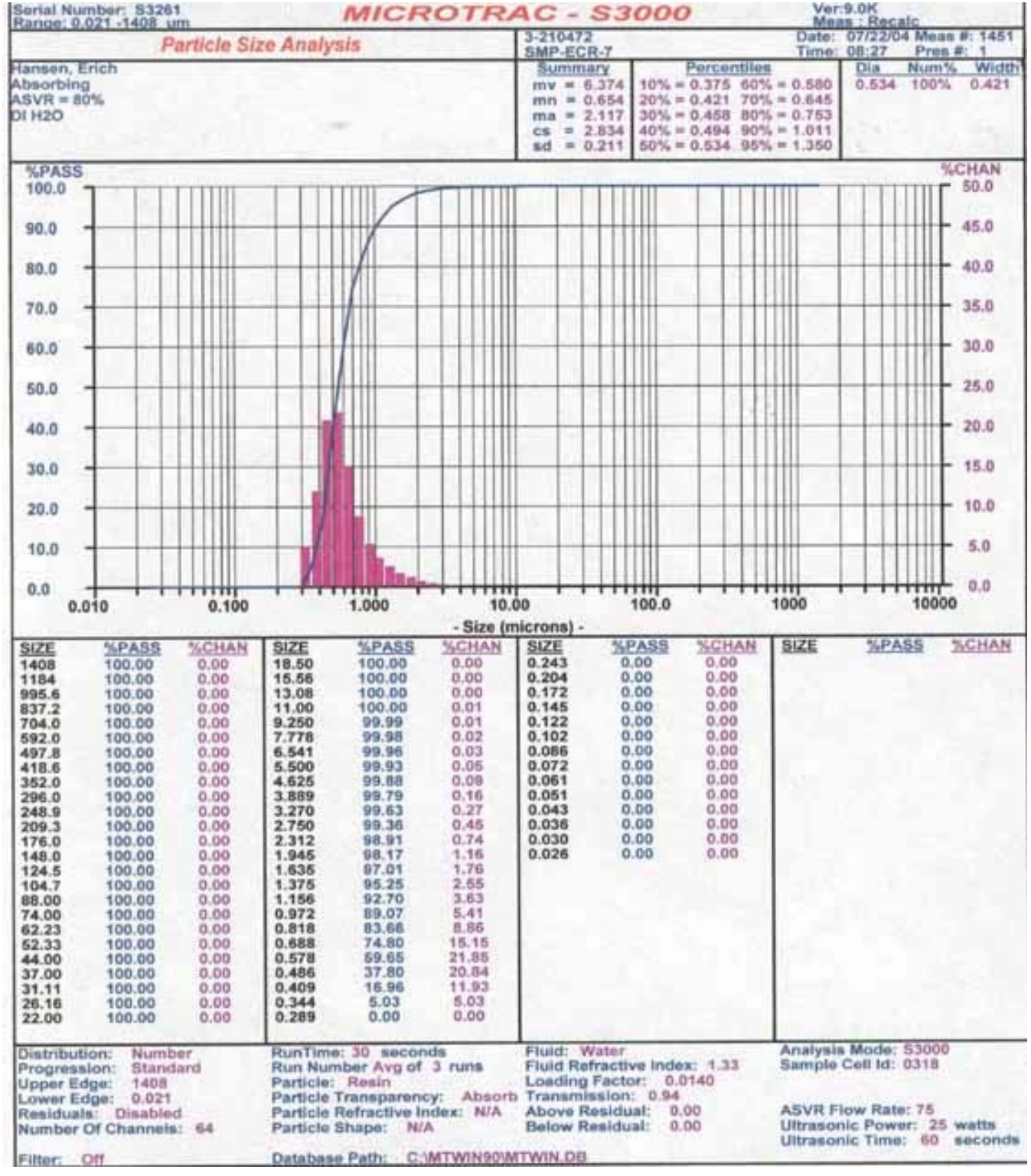

Figure B - 10: SMP-ECR-7 Number Distribution 


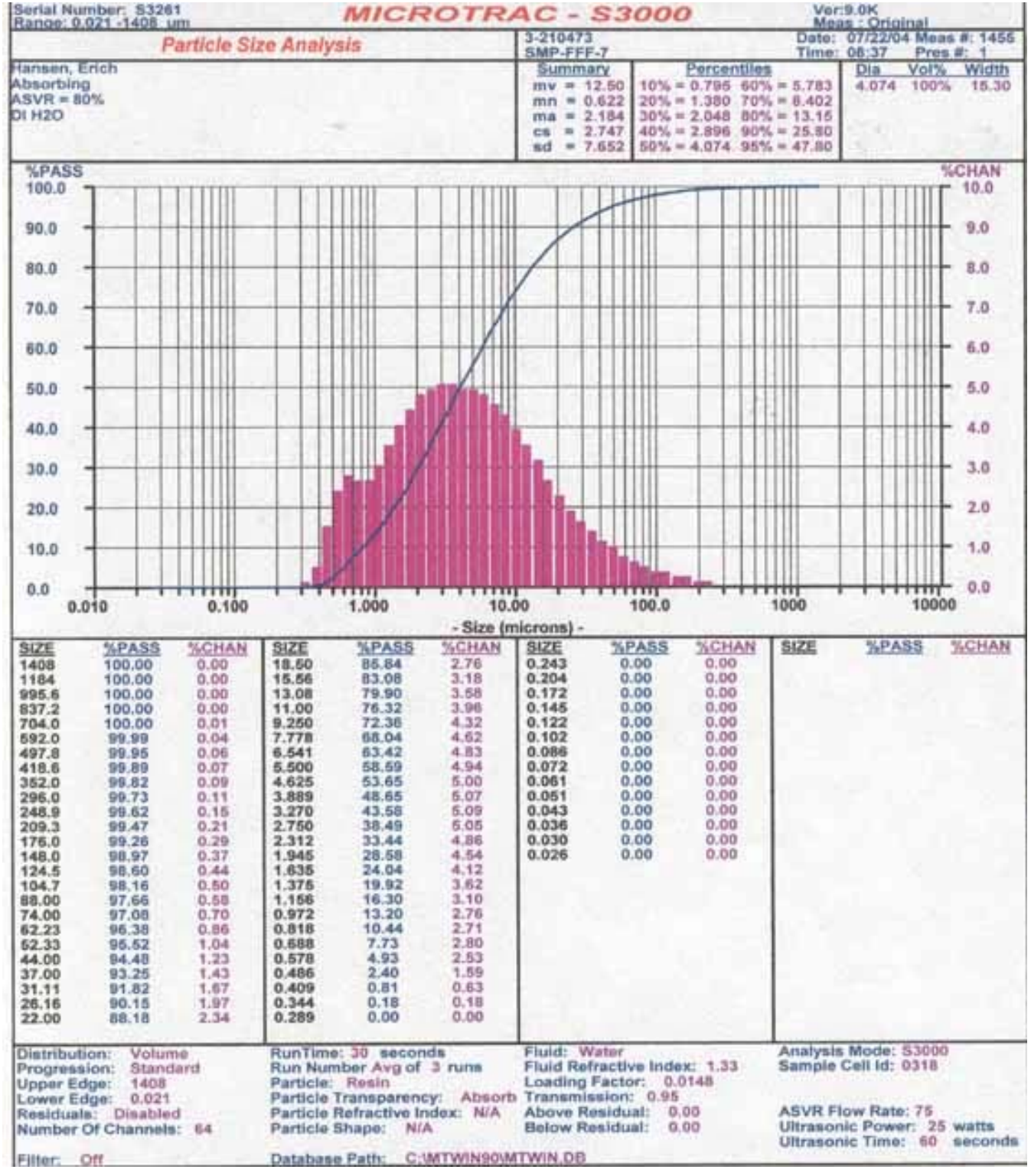

Figure B - 11: SMP-FFF-7 Volume Distribution 


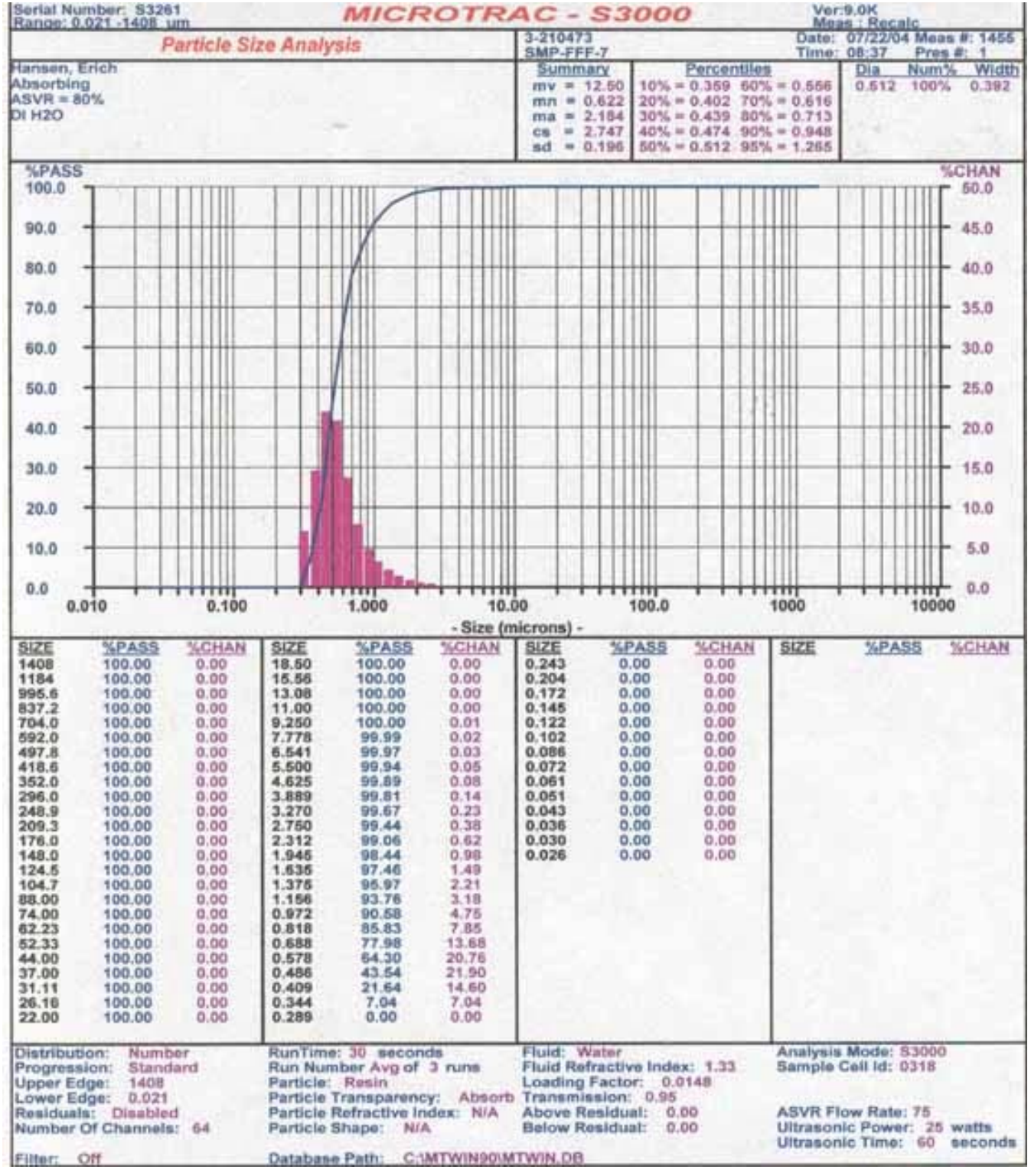

Figure B - 12: SMP-FFF-7 Number Distribution 


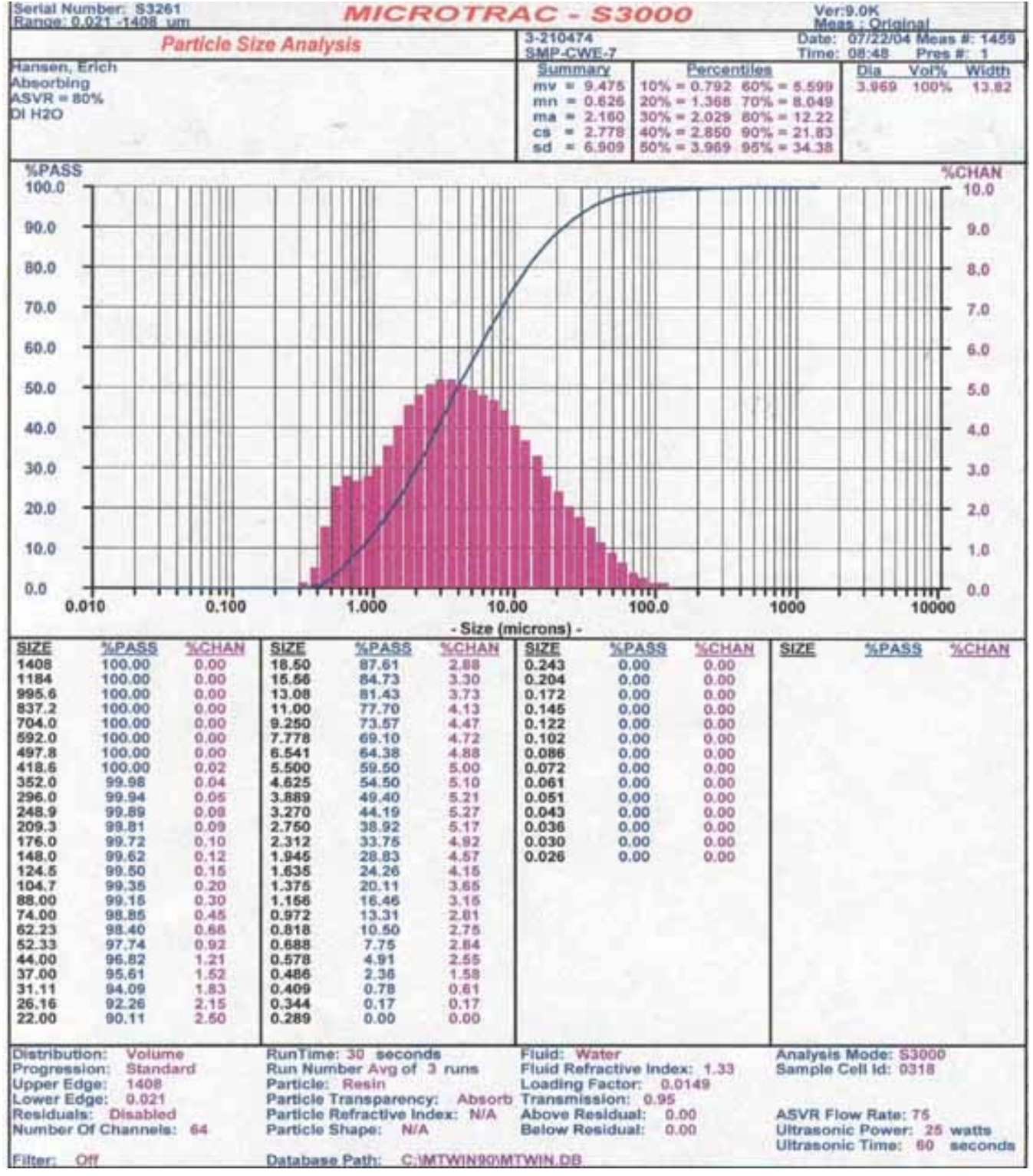

Figure B - 13: SMP-CWE-7 Volume Distribution 


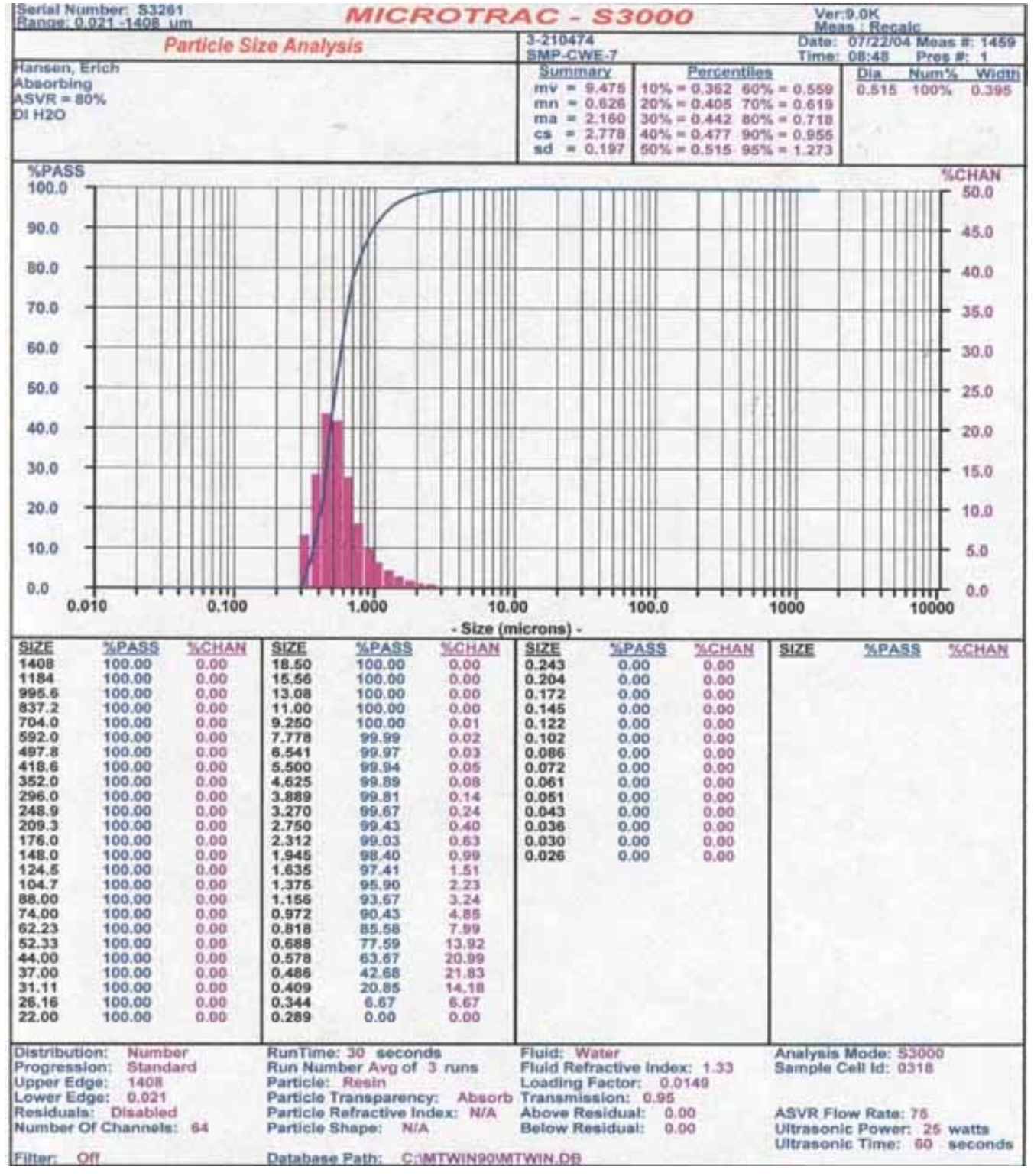

Figure B - 14: SMP-CWE-7 Number Distribution 
WSRC-TR-2004-00401

Revision 0

\section{APPENDIX C: KAOLIN VENDOR B-100 SPECIFICATIONS}


WSRC-TR-2004-00401

Revision 0

TECHNICAL DATA

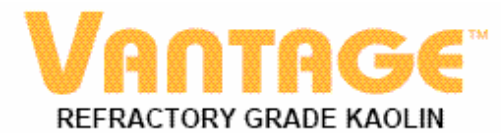

REFRACTORY GRADE KAOLIN

FEATURES AND BENEFITS

HEPHZIBAH, GA

VANTAGE ${ }^{T M}$ refractory grade clays are custom blends of hlghly refractlve kaollnite. These plastlc clays can be employed as the primary component of cast bodles, but are most commonly used to enhance the performance of calcined kaolinic clays. Their excellent plasticlty and dry strength Improve the productlon rate and shape retentlon of the refractory, and a high PCE value helps to extend refractory service llfe.

VANTAGE ${ }^{\mathrm{TM}}$ finds application In a varlety of Intermedlate to high duty flrebricks, shapes, Insulating bricks and saggars where good shape retention and spalling resistance is required. VANTAGE also serves as the plastic component In monollthic refractorles Including castable, ramming and gunning mixes and mortars. Of critlcal Importance In these applications Is a high alumina to alkall ratlo to produce durable, hIghly refractory materlals with excellent stablilty. VANTAGE particle slze distributlons will also help to minimize drying shrinkage prlor to Installation.

All VANTAGE ${ }^{\mathrm{TM}}$ flre clays are mined and processed under rigld QIP $^{5 \mathrm{~m}}$ statistical quality assurance programs. The result is consistent mineralogy, chemical and physical propertles, predictable results in demanding refractory appllcatlons.

CHEMICAL AND ANALYTICAL DATA

Mean Values. These Do Not Represent A Specification.

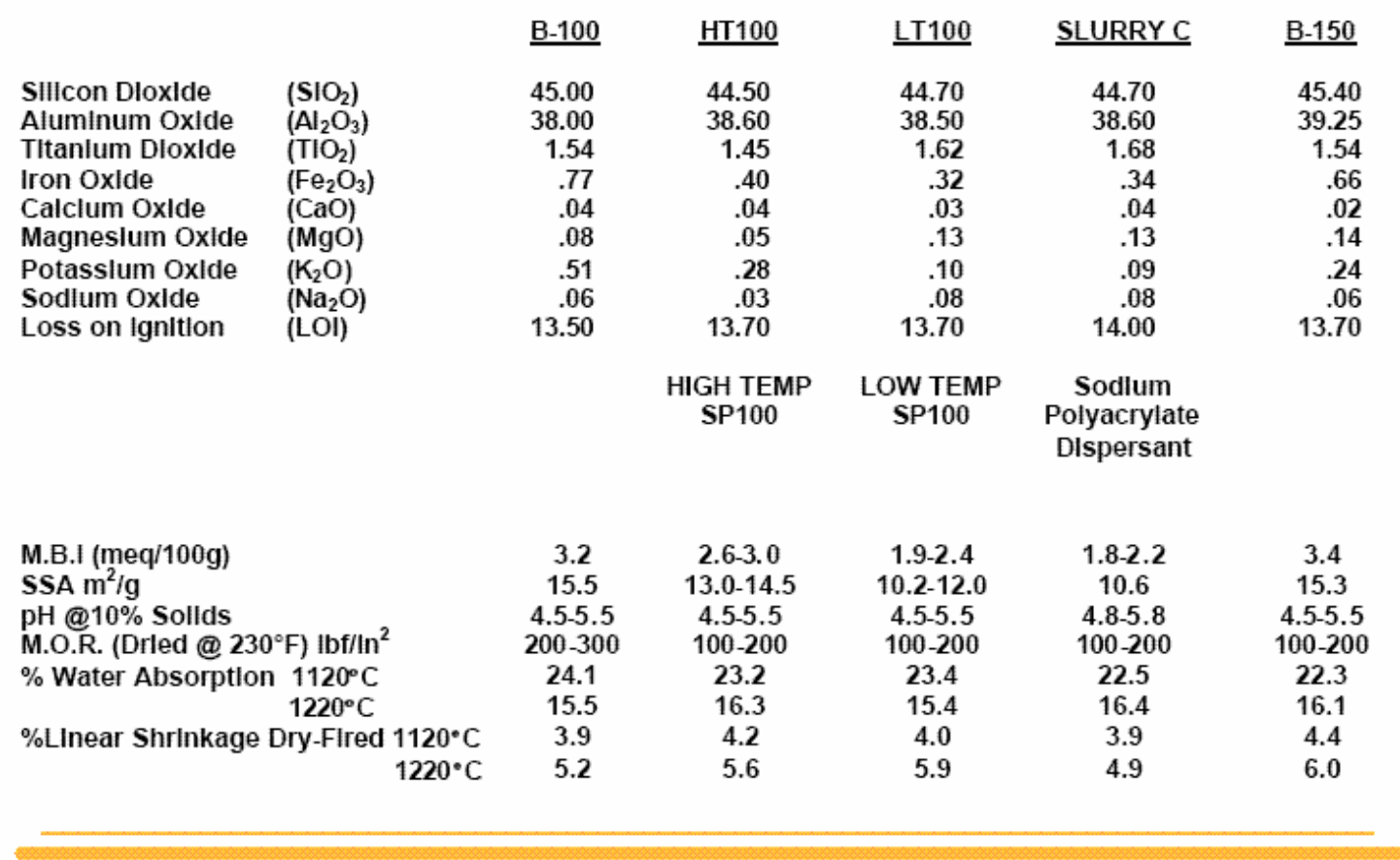


WSRC-TR-2004-00401

Revision 0

\section{TECHNICAL DATA}

\section{VAกTคGE}

PARTICLE SIZE ANALYSIS AND PROPERTIES

Mean Values. These Do Not Represent A Specification

Mean Percent By Welght on OxIde Basls

$\begin{array}{ccccccc} & \text { MICRONS } & \text { B-100 } & \text { HI100 } & \text { LI100 } & \text { SLURRYC } & \text { B-150 } \\ \% \text { FIner } & <20 \mu & 98 & 98 & 97 & 97 & 98 \\ & <10 \mu & 92 & 92 & 88 & 89 & 90 \\ <5 \mu & 83 & 81 & 76 & 75 & 77 \\ <2 \mu & 67 & 58 & 56 & 54 & 58 \\ & <1 \mu & 56 & 42 & 40 & 39 & 47 \\ & <0.5 \mu & 42 & 26 & 22 & 24 & 32\end{array}$

ORDERING INFORMATION

Shipping Polnt:

HEPHZIBAH, GEORGIA

ORIGINATING RAIL CARRIER: NORFOLK SOUTHERN

Avallabllity:

50 LB. BAGS, INTERMEDIATE BULK BAGS, AND BULK TRUCK AND RAIL

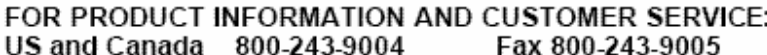

Unmin

Worldwide 203-966-1306 Fax 203-972-1378

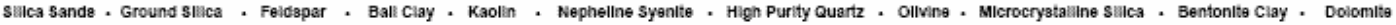

GRADE NUMBERS INDICATE RELATIVE VALUES OR RESULTS. THEY ARE NOT A SPECIFIATION OR WARRANTY OF PERFORMANNCE.

HEALTH HAZARD WARNING: Long term өxposure can cause pneumoco niosis. This material contains crystalline sillca which can cause pneumoconlosis. Pneumoconlosis is a

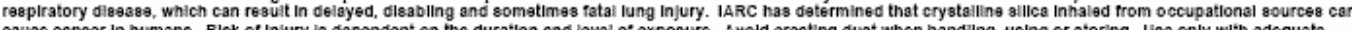
cause cancar in humans. Rlsk of Injury is dependent on the duration and lavel of exposure. Avold crasting dust when handiling, using or storing. Use only with adequate

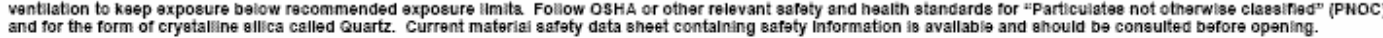

Notice: While information contained herein la correct to the best of our knowledge, Unimin Corporation hereln dleciaims any warrantles as to the accuracy of the same. Recommendations of suggestlons are made without guarantes or representation as to result, Bince conditions of usage are byyond our control. All materials are sold to Unimin Corporation standarde terms and conditions of aale and the conditions that buyer shall make his own tests to determine the suitablity of such product for buyer's purpose. No statement contained haraln ehail be conetrued as a recommendation to infringe any patent.

Kaolinsilica Containing

Vantagerwis a trademark of UNIMIN Corporation or its subsidlaries. All righte reserved.

Hephzibah - Vantage 08:01 